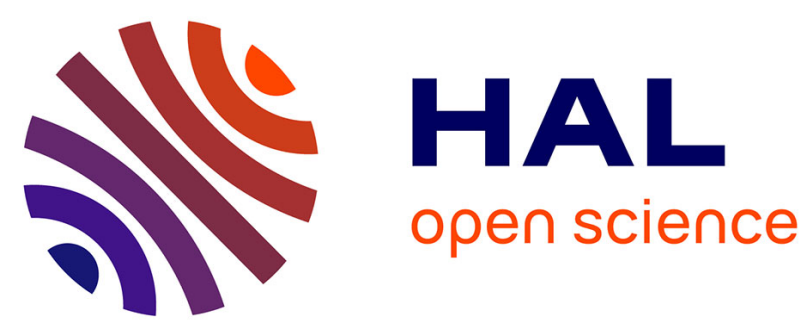

\title{
In vitro and in vivo biological evaluation of new 4,5-disubstituted 1,2,3-triazoles as cis-constrained analogs of combretastatin A4.
}

Núria Mur Blanch, Guy G. Chabot, Lionel Quentin, Daniel Scherman, Stéphane Bourg, Daniel Dauzonne

\section{To cite this version:}

Núria Mur Blanch, Guy G. Chabot, Lionel Quentin, Daniel Scherman, Stéphane Bourg, et al.. In vitro and in vivo biological evaluation of new 4,5-disubstituted 1,2,3-triazoles as cis-constrained analogs of combretastatin A4.. European Journal of Medicinal Chemistry, 2012, 54, pp.22-32. 10.1016/j.ejmech.2012.04.017 . inserm-00709733

\section{HAL Id: inserm-00709733 https://www.hal.inserm.fr/inserm-00709733}

Submitted on 19 Jun 2012

HAL is a multi-disciplinary open access archive for the deposit and dissemination of scientific research documents, whether they are published or not. The documents may come from teaching and research institutions in France or abroad, or from public or private research centers.
L'archive ouverte pluridisciplinaire HAL, est destinée au dépôt et à la diffusion de documents scientifiques de niveau recherche, publiés ou non, émanant des établissements d'enseignement et de recherche français ou étrangers, des laboratoires publics ou privés. 


\section{Accepted Manuscript}

In vitro and in vivo biological evaluation of new 4,5-disubstituted 1,2,3-triazoles as cisconstrained analogues of combretastatin A4

Núria Mur Blanch, Guy G. Chabot, Lionel Quentin, Daniel Scherman, Stéphane Bourg, Daniel Dauzonne

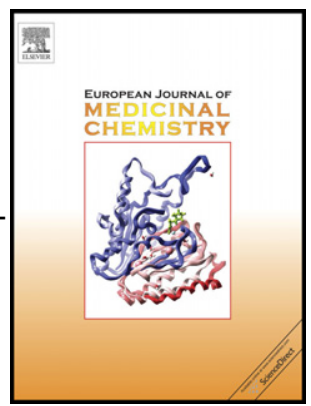

PII: S0223-5234(12)00269-3

DOI: 10.1016/j.ejmech.2012.04.017

Reference: EJMECH 5487

To appear in: European Journal of Medicinal Chemistry

Received Date: 19 December 2011

Revised Date: 11 April 2012

Accepted Date: 12 April 2012

Please cite this article as: M. Blanch, G.G. Chabot, L. Quentin, D. Scherman, S. Bourg, D. Dauzonne, In vitro and in vivo biological evaluation of new 4,5-disubstituted 1,2,3-triazoles as cis-constrained analogues of combretastatin A4, European Journal of Medicinal Chemistry (2012), doi: 10.1016/ j.ejmech.2012.04.017

This is a PDF file of an unedited manuscript that has been accepted for publication. As a service to our customers we are providing this early version of the manuscript. The manuscript will undergo copyediting, typesetting, and review of the resulting proof before it is published in its final form. Please note that during the production process errors may be discovered which could affect the content, and all legal disclaimers that apply to the journal pertain. 


\section{Graphical abstract}
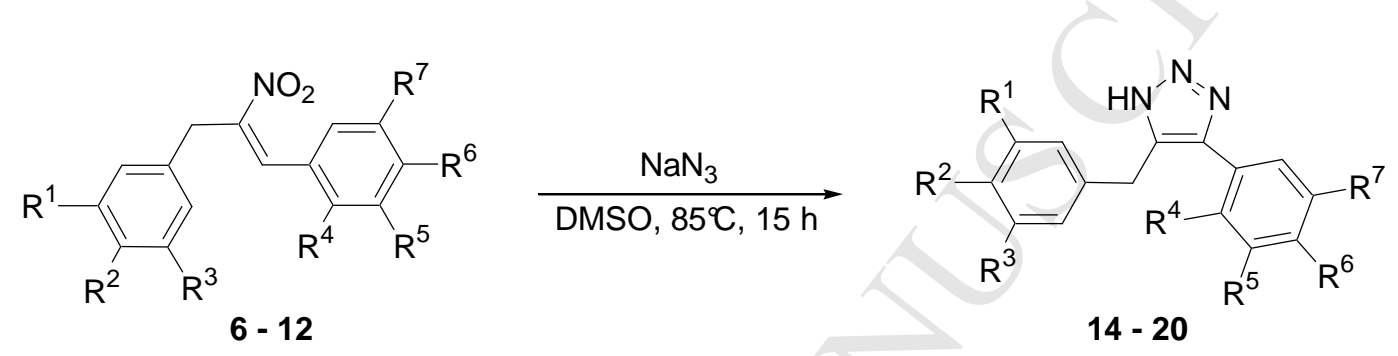

Amongst the synthesized compounds, the best rounding up activity was obtained with

compounds 11 and $19\left(\mathrm{R}^{1}=\mathrm{R}^{2}=\mathrm{R}^{3}=\mathrm{R}^{6}=\mathrm{OCH}_{3}, \mathrm{R}^{4}=\mathrm{R}^{5}=\mathrm{H}, \mathrm{R}^{7}=\mathrm{OH}\right)$ with concentrations of 0.13 and $0.2 \mu \mathrm{M}$, respectively. 


\section{In vitro and in vivo biological evaluation of new 4,5-disubstituted}

\section{1,2,3-triazoles as cis-constrained analogues of combretastatin A4}

\section{Núria Mur Blanch ${ }^{\mathrm{a}, \mathrm{b}}$, Guy G. Chabot ${ }^{\mathrm{c}, \mathrm{d}, *}$, Lionel Quentin ${ }^{\mathrm{c}, \mathrm{d}}$, Daniel Scherman ${ }^{\mathrm{c}, \mathrm{d}}$, Stéphane Bourg ${ }^{\mathrm{e}}$, Daniel Dauzonne $\mathrm{a}^{\mathrm{ab}, \text {,* }}$}

${ }^{\text {a }}$ Institut Curie, Centre de Recherche, 26 rue d'Ulm, F-75005 Paris, France

${ }^{\mathrm{b}}$ CNRS, UMR176, 26 rue d'Ulm, F-75005 Paris, France

${ }^{\mathrm{c}}$ Paris Descartes University; Sorbonne Paris Cité; Faculty of Pharmacy, F-75006 Paris, France

d INSERM U1022; CNRS UMR8151; Chimie ParisTech; Chemical, Genetic and Imaging Pharmacology Laboratory, F-75006 Paris, France

${ }^{\text {e }}$ Fédération de Recherche Physique et Chimie du Vivant; Université d'Orléans-CNRS, FR 2708, avenue Charles Sadron, 45071 Orléans Cedex 2, France

* Correspondence to:

Daniel Dauzonne, Institut Curie, Centre de Recherche (CNRS UMR176), 26 rue d'Ulm, F-75005 Paris, France. Tel. +33 (0)1 562466 61; Email: daniel.dauzonne@ curie.fr

or

Guy G. Chabot, Faculty of Pharmacy, INSERM U1022 and CNRS UMR8151, Paris Descartes University, 4 avenue de l'Observatoire, F75006 Paris, France. Tel. +33 (0)1 537395 71; Email: guy.chabot@parisdescartes.fr

Keywords: antivascular agents, combretastatin analogues, triazoles, endothelial cells, tubulin polymerization, cytotoxicity 


\section{Abstract}

To find new and better antivascular agents for cancer therapy, a series of combretastatin A4 (CA4) analogues were prepared from 1,3-diaryl-2-nitroprop-1-enes (6-12) obtained in a two-step synthesis from appropriate arylaldehydes and 2-aryl-1-nitroethanes (4 or $\mathbf{5})$. Treatment of these 1,3diaryl-2-nitroprop-1-enes 6-12 by sodium azide in DMSO yielded the targeted compounds. The synthesized 1,2,3-triazoles disubstituted in 4- and 5-positions by one benzyl group and one aryl nucleus have also been tested for biological activities involved in antivascular action. It was found that several new compounds exhibited interesting biological activities in the nanomolar or low micromolar range, in terms of rounding up of endothelial cells, inhibition of tubulin polymerization, and cytotoxicity on B16 melanoma cancer cells. In silico docking studies of $\mathbf{1 1}$ and $\mathbf{1 9}$ within the active site of tubulin were also carried out in order to rationalize the inhibitory properties of these compounds and further understand their inhibition mechanism. In vivo evaluation of compounds $\mathbf{1 1}$ and $\mathbf{1 9}$ in mice bearing colon 26 carcinoma indicated modest anticancer activity.

\section{Graphical abstract}
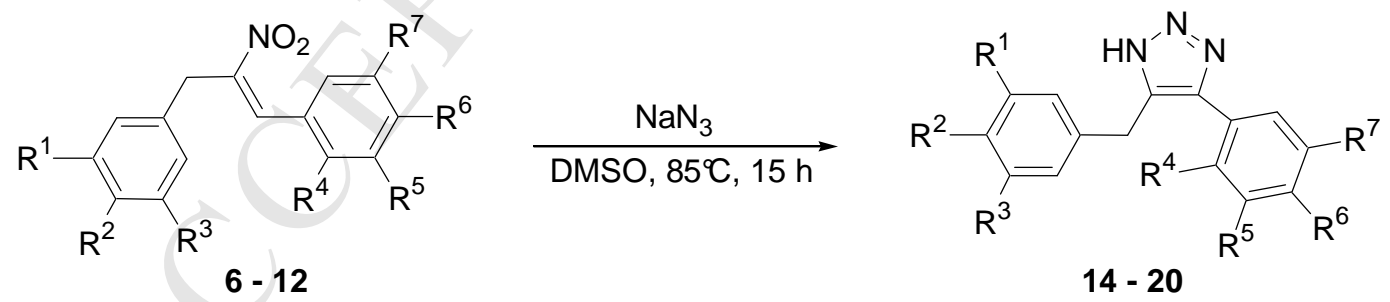

Amongst the synthesized compounds, the best rounding up activity was obtained with compounds $\mathbf{1 1}$ and $19\left(\mathrm{R}^{1}=\mathrm{R}^{2}=\mathrm{R}^{3}=\mathrm{R}^{6}=\mathrm{OCH}_{3}, \mathrm{R}^{4}=\mathrm{R}^{5}=\mathrm{H}, \mathrm{R}^{7}=\mathrm{OH}\right)$ with concentrations of 0.13 and $0.2 \mu \mathrm{M}$, respectively. 


\section{Introduction}

Tumor vasculature is an attractive target for cancer therapy because solid tumors require blood vessels to grow and metastasize [1-4]. This requirement for neovascularization to allow tumors to grow beyond a certain threshold size drew attention to the potential therapeutic agents that may act on angiogenesis which occurs in several steps of the cancer process and offers several targets for intervention [1-10].

Tumor vascularization is the result of pro-angiogenic factors and inhibitors and involves the interaction between endothelial cells and extracellular matrix. Various approaches have been developed to improve tumor control through the vascular targeting agents which can be divided into antiangiogenic and vascular-disrupting agents (VDAs) [11-14].

Considering the VDAs $[15,16]$, the best active compounds that have been found to date are acting on tubulin polymerization. In this context, the molecule that emerged as one of the most potent is combretastatin A4 (CA4 1) which is a cis-stilbene derivative that was selected among seventeen combretastatin compounds originally isolated from the South African bushwillow tree Combretum caffrum Kuntze (Combretaceae) by Pettit and co-workers [17-19].

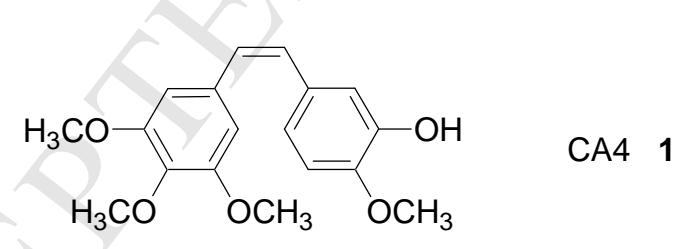

CA4 (1) is a strong inhibitor of tubulin polymerization and can induce an important cytotoxicity in the nanomolar range against various cancer cell lines, including multi-drug resistant ones [20]. To be active, 1 requires the cis-configuration, but it is known that it can easily isomerize into its trans inactive form [21-22].

In order to stabilize the active configuration, numerous teams have synthesized a wide range of various cis-restricted analogues of $\mathbf{1}$. The literature has been repetitively reviewed during the past decade [23-32] and, among the wide range of published heterocyclic compounds, the triazole derivatives have received little attention. In this context, some 3,4-disubstituted 1,2,4-triazole [33, 34], 1,4-disubstituted 1,2,3-triazole [35-38], 1,5-disubstituted 1,2,3-triazole [36-40] and 4,5disubstituted 1,2,3-triazole [40-42] showed interesting activities in terms of tubulin polymerization 
inhibition and/or cytotoxicity. To our knowledge, only one report [37] deals with triazoles having vicinal benzyl and phenyl substituents (in the relative 1,5-positions) designed in order to confer to the molecule a higher degree of conformational freedom.

In the context of hitherto unknown 1,2,3-triazoles disubstituted in the 4- and 5-positions by one aryl group and one benzyl substituent, the present study was undertaken to provide information on the biological activities of these compounds. We report here that several compounds of this series present interesting biological activities in the nanomolar or low micromolar range, in terms of rounding up of endothelial cells, inhibition of tubulin polymerization, and cytotoxicity on cancer cells. In silico docking studies of $\mathbf{1 1}$ and $\mathbf{1 9}$ within the active site of tubulin were also carried out and we also performed a preliminary in vivo evaluation of compounds $\mathbf{1 1}$ and $\mathbf{1 9}$ which revealed a modest anticancer activity in mice bearing colon 26 carcinoma tumors.

\section{Results and Discussion}

\subsection{Chemistry}

The title compounds were prepared starting from 1,3-diaryl-2-nitroprop-1-enes (6-12) obtained according to a procedure already described by one of us [43] from appropriate arylaldehydes and some 2-aryl-1-nitroethanes ( 4 or 5 ) by refluxing in toluene in the presence of dimethylammonium chloride and a small amount of potassium fluoride. The required nitro derivatives $\mathbf{4}$ and $\mathbf{5}$ were synthesized by a two-step procedure starting from suitable benzaldehydes via the corresponding 2-aryl-1-nitroethenes ( 2 or $\mathbf{3}$, respectively), as depicted in Scheme 1.

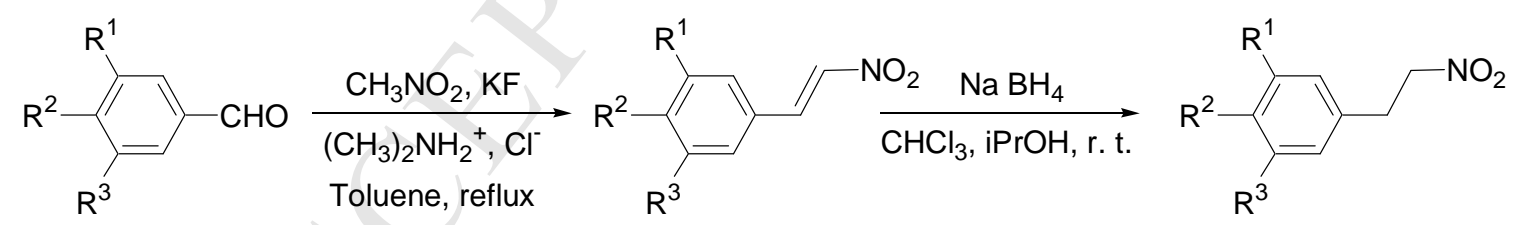

$$
\begin{array}{ll}
\mathbf{2}: \mathrm{R}^{1}=\mathrm{OH}, \mathrm{R}^{2}=\mathrm{OCH}_{3}, \mathrm{R}^{3}=\mathrm{H} & \mathbf{4}: \mathrm{R}^{1}=\mathrm{OH}, \mathrm{R}^{2}=\mathrm{OCH}_{3}, \mathrm{R}^{3}=\mathrm{H} \\
\mathbf{3}: \mathrm{R}^{1}=\mathrm{R}^{2}=\mathrm{R}^{3}=\mathrm{OCH}_{3} & \mathbf{5}: \mathrm{R}^{1}=\mathrm{R}^{2}=\mathrm{R}^{3}=\mathrm{OCH}_{3}
\end{array}
$$

Scheme 1

Subsequent treatment of these 1,3-diaryl-2-nitroprop-1-enes 6-12 by sodium azide in dimethylsulfoxyde at $85^{\circ} \mathrm{C}$, following a methodology reported by Quiclet-Sire and Zard [44], gave 
the desired compounds as shown in Scheme 2, with good yield in most cases (cf. Experimental part).

In a similar way, the indole derivative $\mathbf{2 1}$ has been prepared in 93\% yield from the already known nitroethene $\mathbf{1 3}$ previously synthesized according to reference [43] (Scheme 3).

The amino derivative 22 was easily obtained in $88 \%$ yield by catalytic hydrogenation in THF from its nitro precursor $\mathbf{1 7}$ as presented in Scheme 4.

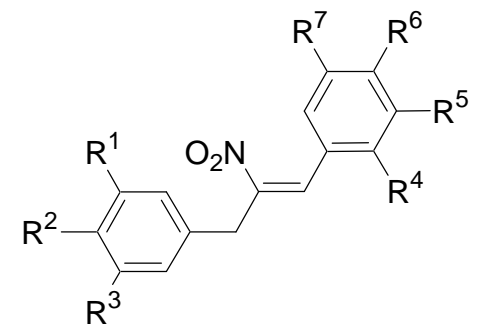

$6: \mathrm{R}^{1}=\mathrm{OH}, \mathrm{R}^{2}=\mathrm{OCH}_{3}, \mathrm{R}^{3}=\mathrm{H}$

$\mathrm{R}^{4}=\mathrm{H}, \mathrm{R}^{5}=\mathrm{OCH}_{3}, \mathrm{R}^{6}=\mathrm{OCH}_{3}, \mathrm{R}^{7}=\mathrm{OCH}_{3}$

$7: \mathrm{R}^{1}=\mathrm{OCH}_{3}, \mathrm{R}^{2}=\mathrm{OCH}_{3}, \mathrm{R}^{3}=\mathrm{OCH}_{3}$

$\mathrm{R}^{4}=\mathrm{H}, \mathrm{R}^{5}=\mathrm{H}, \mathrm{R}^{6}-\mathrm{R}^{7}=\mathrm{OCH}_{2} \mathrm{O}$

$8: \mathrm{R}^{1}=\mathrm{OCH}_{3}, \mathrm{R}^{2}=\mathrm{OCH}_{3}, \mathrm{R}^{3}=\mathrm{OCH}_{3}$

$\mathrm{R}^{4}=\mathrm{Cl}, \mathrm{R}^{5}=\mathrm{H}, \mathrm{R}^{6}=\mathrm{Cl}, \mathrm{R}^{7}=\mathrm{H}$

$9: \mathrm{R}^{1}=\mathrm{OCH}_{3}, \mathrm{R}^{2}=\mathrm{OCH}_{3}, \mathrm{R}^{3}=\mathrm{OCH}_{3}$

$\mathrm{R}^{4}=\mathrm{H}, \mathrm{R}^{5}=\mathrm{H}, \mathrm{R}^{6}=\mathrm{OCH}_{3}, \mathrm{R}^{7}=\mathrm{NO}_{2}$

$10: R^{1}=\mathrm{OCH}_{3}, \mathrm{R}^{2}=\mathrm{OCH}_{3}, \mathrm{R}^{3}=\mathrm{OCH}_{3}$

$\mathrm{R}^{4}=\mathrm{H}, \mathrm{R}^{5}=\mathrm{H}, \mathrm{R}^{6}=\mathrm{OCH}_{3}, \mathrm{R}^{7}=\mathrm{F}$

$11: R^{1}=\mathrm{OCH}_{3}, R^{2}=\mathrm{OCH}_{3}, \mathrm{R}^{3}=\mathrm{OCH}_{3}$

$\mathrm{R}^{4}=\mathrm{H}, \mathrm{R}^{5}=\mathrm{H}, \mathrm{R}^{6}=\mathrm{OCH}_{3}, \mathrm{R}^{7}=\mathrm{OH}$

$12: R^{1}=\mathrm{OCH}_{3}, \mathrm{R}^{2}=\mathrm{OCH}_{3}, \mathrm{R}^{3}=\mathrm{OCH}_{3}$

$\mathrm{R}^{4}=\mathrm{H}, \mathrm{R}^{5}=\mathrm{H}, \mathrm{R}^{6}=\mathrm{OH}, \mathrm{R}^{7}=\mathrm{OCH}_{3}$

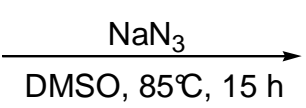

DMSO, $85^{\circ} \mathrm{C}, 15 \mathrm{~h}$

\section{Scheme 2}

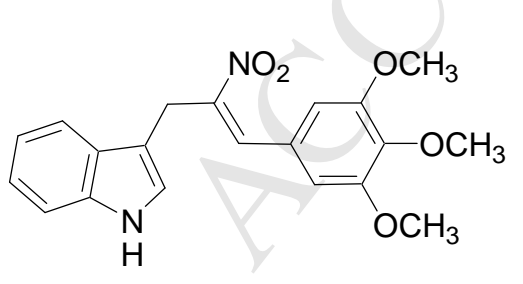

13

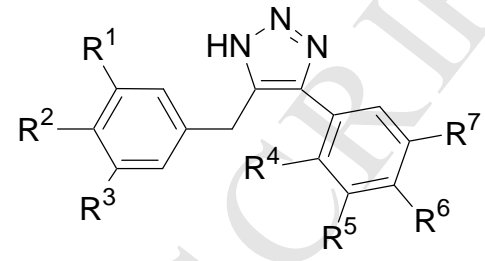

$14: \mathrm{R}^{1}=\mathrm{OH}, \mathrm{R}^{2}=\mathrm{OCH}_{3}, \mathrm{R}^{3}=\mathrm{H}$

$\mathrm{R}^{4}=\mathrm{H}, \mathrm{R}^{5}=\mathrm{OCH}_{3}, \mathrm{R}^{6}=\mathrm{OCH}_{3}, \mathrm{R}^{7}=\mathrm{OCH}_{3}$

15: $\mathrm{R}^{1}=\mathrm{OCH}_{3}, \mathrm{R}^{2}=\mathrm{OCH}_{3}, \mathrm{R}^{3}=\mathrm{OCH}_{3}$

$\mathrm{R}^{4}=\mathrm{H}, \mathrm{R}^{5}=\mathrm{H}, \mathrm{R}^{6}-\mathrm{R}^{7}=\mathrm{OCH}_{2} \mathrm{O}$

$16: \mathrm{R}^{1}=\mathrm{OCH}_{3}, \mathrm{R}^{2}=\mathrm{OCH}_{3}, \mathrm{R}^{3}=\mathrm{OCH}_{3}$

$\mathrm{R}^{4}=\mathrm{Cl}, \mathrm{R}^{5}=\mathrm{H}, \mathrm{R}^{6}=\mathrm{Cl}, \mathrm{R}^{7}=\mathrm{H}$

$17: R^{1}=\mathrm{OCH}_{3}, \mathrm{R}^{2}=\mathrm{OCH}_{3}, \mathrm{R}^{3}=\mathrm{OCH}_{3}$

$\mathrm{R}^{4}=\mathrm{H}, \mathrm{R}^{5}=\mathrm{H}, \mathrm{R}^{6}=\mathrm{OCH}_{3}, \mathrm{R}^{7}=\mathrm{NO}_{2}$

$18: R^{1}=\mathrm{OCH}_{3}, R^{2}=\mathrm{OCH}_{3}, \mathrm{R}^{3}=\mathrm{OCH}_{3}$

$\mathrm{R}^{4}=\mathrm{H}, \mathrm{R}^{5}=\mathrm{H}, \mathrm{R}^{6}=\mathrm{OCH}_{3}, \mathrm{R}^{7}=\mathrm{F}$

$19: \mathrm{R}^{1}=\mathrm{OCH}_{3}, \mathrm{R}^{2}=\mathrm{OCH}_{3}, \mathrm{R}^{3}=\mathrm{OCH}_{3}$

$\mathrm{R}^{4}=\mathrm{H}, \mathrm{R}^{5}=\mathrm{H}, \mathrm{R}^{6}=\mathrm{OCH}_{3}, \mathrm{R}^{7}=\mathrm{OH}$

$20: R^{1}=\mathrm{OCH}_{3}, \mathrm{R}^{2}=\mathrm{OCH}_{3}, \mathrm{R}^{3}=\mathrm{OCH}_{3}$

$\mathrm{R}^{4}=\mathrm{H}, \mathrm{R}^{5}=\mathrm{H}, \mathrm{R}^{6}=\mathrm{OH}, \mathrm{R}^{7}=\mathrm{OCH}_{3}$

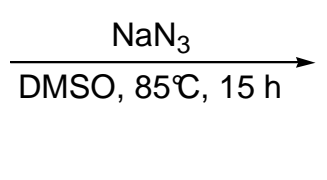

$\underset{\mathrm{DMSO}, 85^{\circ} \mathrm{C}, 15 \mathrm{~h}}{\longrightarrow}$

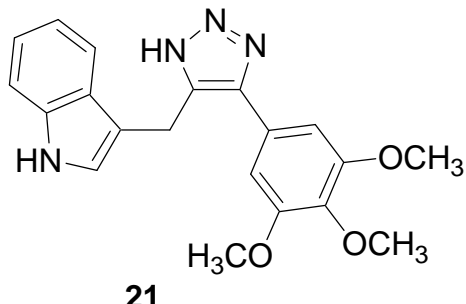

21

\section{Scheme 3}


<smiles>COc1ccc(-c2nn[nH]c2Cc2cc(OC)c(OC)c(OC)c2)cc1[N+](=O)[O-]</smiles>

17

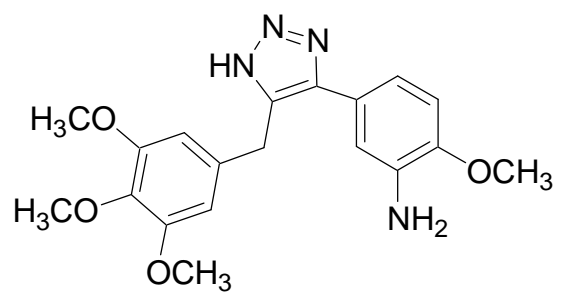

22

\section{Scheme 4}

The known compounds 23, 24 and 25 have been prepared from the appropriate 1,3-diaryl-2nitropropenes according to reference [43].

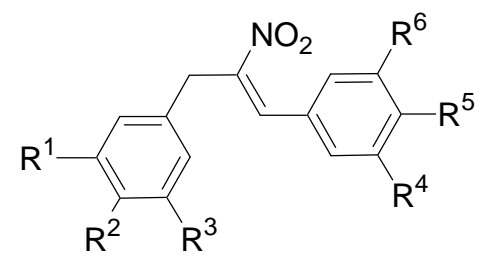

\section{2. Biological activities}

To evaluate the potential antivascular activity of the new cis-constrained analogues of $\mathbf{1}$, we first assessed their rounding up activity on endothelial cells, which is considered to be predictive of potential in vivo antivascular activity [45]. The compounds were also tested for their inhibition of tubulin polymerization and their cytotoxic activity on the murine B16 melanoma cell line.

\subsubsection{Morphological activity}

Table 1 presents the rounding up activity data for the synthesized combretastatin analogues from the most active to the less active compounds. Compared to the reference compound (1) which could elicit a rounding up of endothelial cells at very low concentrations $(6 \mathrm{nM})$, seven compounds of our series showed interesting rounding up activity below $1 \mu \mathrm{M}$ for a 2 hour exposure time (19, 11, 22, 7, 6, 14 and 10). A representative photograph depicting the rounding up activity of compound 19 at a concentration of $1 \mu \mathrm{M}$ is shown in Figure 1 and compared to CA4. It is noteworthy that rounding up activity was observed at concentration as low as $0.13 \mu \mathrm{M}$ for compound 19. Alteration of endothelial cell morphology is a distinctive feature of the activity of VDAs which is correlated with cytoskeleton disorganization [45].

\subsubsection{Tubulin polymerization inhibition}


The compound concentrations needed to inhibit tubulin polymerization by $50 \%$ are also shown in Table 1. We observed that the best compounds for tubulin activity were also the ones that could elicit a rounding up of endothelial cells at low concentrations. It is noteworthy that a very good linear correlation exists between the inhibition of tubulin polymerization and the morphological activity (rounding up) on endothelial cells for the most active compounds presenting morphological activity at concentrations of less than $10 \mu \mathrm{M}$ (Figure 2).

\subsubsection{Cytotoxicity}

Finally our new combretastatin analogues were also evaluated for their cytotoxicity on the B16 melanoma cell line. For this biological activity, the correlation with rounding up activity was less evident. With the exception of compounds 22, 14 and 18, which appear to be outliers, a relative good correlation was nonetheless observed between cytotoxicity and rounding up activity for the best morphologically active compounds $(<10 \mu \mathrm{M})$.

\subsubsection{Structure-activity relationships}

Beside the well-known requirement of the 3,4,5-trimethoxyphenyl group for optimal biological activity of combretastatin analogues [21-30], we also noted the following interesting features for the new 4,5-disubstituted 1,2,3-triazoles and related 1,3-diaryl-2-nitroprop-1-enes. With regards to the nitroalkene and triazole series, we noted that the compounds the most similar to $\mathbf{1}$, i.e., those bearing a methoxyl group in the para position together with an hydroxy substituent in the meta position, were among the most potent derivatives (e.g., 19, 11, 6, 14). In this context, it must be pointed out that compounds belonging to series $\mathrm{B}$, where the 3,4,5-trimethoxyphenyl nucleus is directly connected to the double bond of the triazole ring, are relatively less active compared to their analogues having a 3,4,5-trimethoxybenzyl substituent (compare 19 vs 14, 11 vs 6).

Concerning the inversion of the relative position of methoxy and hydroxy groups (compare 12 with 11 and 6, or 20 with 19 or 14) we noted that biological activities were noticeably diminished, in particular concerning tubulin polymerization inhibition. We also noted that the presence of a second methoxy group on the other meta position led to diminished biological activity (compare 25 vs 12).

Although they remain slightly less efficient than 11 or 19, those derivatives in which the meta-hydroxy is replaced by a fluorine atom (10 or 18), a nitro group (9 or 17) or an amino substituent (22) led, particularly in this latter case, to fairly good results $\left(\mathrm{NH}_{2}>\mathrm{F}>\mathrm{NO}_{2}\right)$.

However, the replacement of the 4-methoxy-3-hydroxybenzene nucleus by a 3,4methylenedioxybenzene (compare 11 to 7 and 19 to 15), by a 3,4,5-trimethoxybenzene (compare 11 
to 24), by dichlorobenzenes (compare 11 to 8 or 23 and 19 to 16) or by a 3-indolyl (compare 6 to

13 and 14 to 21 ) were found unfavorable to biological activities.

Finally, with the exception of the couple 11/19 where the measured biological activities are very close, the comparison between the nitroalkene series (6-13) and the triazole compounds (1422) demonstrates that the nitroalkenes 6-13, having a higher degree of conformational freedom, are more active than their corresponding triazole derivatives.

Considering the relatively good in vitro activities of compounds $\mathbf{1 1}$ and $\mathbf{1 9}$ in terms of cytotoxicity, rounding up of endothelial cells and inhibition of tubulin polymerization, the putative mechanism of action of these compounds is probably close to that of CA4.

\subsection{Molecular modeling}

In order to compare the putative binding mode of our cis-constrained analogues of CA4 and combretastatin itself, docking studies were carried out by using the reported high-resolution crystal structure of the tubulin-DAMA-colchicine(CN-2) complex (PDB ID: 1SA0) [46] as it was done on other heterocyclic analogues of CA4 [47]. The colchicine site, well described in two recent reviews $[48,49]$, is a deep pocket located at the $\alpha-\beta$ interface of tubulin heterodimers. Massaroti et al. [49] identified three zones of interaction reproduced in Figure 3. The trimethoxyphenyl ring (TMP or A ring) of $\mathrm{CN}-2$ lies in a hydrophobic pocket of zone 2 while the other side of the molecule (C ring) interacts in zone 1 by van der Waals contacts. Furthermore two residues are highlighted as they are often involved in hydrogen bond interactions with ligands: Cys241 $\beta$ and Val181 $\alpha$. It should be noted that the residue numbering system we used is derived from the crystal structure [46].

Docking simulations were performed with GOLD software version 5.1 [50] (see docking protocol for more details). Our protocol was validated by its ability to reproduce the crystal complex structure CN-2 / tubulin by docking the ligand extracted from the complex. Superimposition, not shown, of our best docked pose on the crystal structure gave an RMSD deviation, based on heavy atoms, of $0.92 \AA$. The $\mathrm{C}$ ring is involved in hydrogen bond with Val181 $\alpha$. The TMP ring is at a good distance of Cys241 $\beta$ to be involved in hydrogen bond, but the polar hydrogen atom of cystein is not properly directed to the methoxy oxygen atoms of $\mathrm{CN}-2$.

The next step was the docking of CA4. The conformer with the lowest energy resulting from a conformational analysis was chosen as starting point. The pose, corresponding to the best docking score of the 100 conformations generated during the docking process, is superimposed to $\mathrm{CN}-2$ crystal structure (Figure 3). It exhibits a similar binding mode, where the TMP rings are buried in the same hydrophobic pocket and, where the oxygen atom of the hydroxyl group is involved in hydrogen bond with Val $181 \alpha$, in accordance with the $\mathrm{C}$ ring of $\mathrm{CN}-2$. 
Initial structures of $\mathbf{1 1}$ and tautomers of $\mathbf{1 9}$ were prepared similarly to CA4. The best docked poses were then selected to be superimposed, on Figure 3, on the CA4 conformation previously obtained. $\mathbf{1 1}$ docked in a very similar position relative to CA4, establishing again a hydrogen bond with Val $181 \alpha$. Although the oxygen acceptor atoms of nitro group are close to the hydrogen atoms of Ala $250 \beta$ or Asp251 $\beta$, our model does not exhibit such hydrogen bonds.

Among the three tautomers of $\mathbf{1 9}$, we can distinguish the one were hydrogen is on the central nitrogen. It adopts a CN2-like pose but not in the top 10 of scored conformations. In this case, not shown, the triazole group points its hydrogen atom to the amino group of Asn101 $\alpha$ without favorable interaction. The two other tautomers poses differ only by the hydrogen atom position. In the first case, not shown, this hydrogen interacts via a hydrogen bond with the carbonyl group of Asn $258 \beta$. In the second case, represented on Figure 3, the hydrogen is at the opposite side of the ring and is not involved in a hydrogen bond. It should be noted that the poses of those two last tautomers have a very similar score. The three tautomers have in common the pockets, where their aromatic rings are embedded but shifted regarding those of CA4. This shift result is the loss of hydrogen bond with Val $181 \alpha$.

To conclude, we observed the non-coplanar cisoid arrangement of the two aromatic rings, highlighted on Figure 3, of CA4 and its analogues. This arrangement is described as essential for the biological activity [51], but it is not sufficient because the loss of some hydrogen bonds and the absence of new ones could explain the lower biological activity than the one observed with CA4.

\subsection{Evaluation of antitumor activity in colon 26-bearing mice}

Based on their good in vitro biological activities, compounds 11 and 19 were selected for further in vivo testing in colon 26 tumor bearing mice. The colon 26 tumor was chosen because this model is responsive to antivascular agents [52]. Figure 4 presents the tumor volume of controls receiving the solvent and treated animals receiving compound $\mathbf{1 1}$ or $\mathbf{1 9}$ at their highest non toxic dose, i.e., $150 \mathrm{mg} / \mathrm{kg}$ for 11 and $100 \mathrm{mg} / \mathrm{kg}$ for 19, administered intraperitoneally for two weeks on days 3-7 and 10-14 after tumor implantation (day 0). Compounds 11 and 19 presented similar percent $\mathrm{T} / \mathrm{C}$ values of $52 \%$ and $60 \%$, respectively, measured when control tumors reached 1500 $\mathrm{mm}^{3}$. The tumor growth delay of treated mice compared to controls (T-C) was 2 days for compound 11 and 2.7 days for compound 19.

Although 11 and 19 caused a significant delay in tumor growth, this antitumor efficacy can be regarded as modest activity considering that a $\mathrm{T} / \mathrm{C}$ value of $42 \%$ is considered the minimum level for activity according to the National Cancer Institute criteria. It is however possible that other 
schedules of administration and/or doses could contribute to improve the antitumor activity of these compounds.

\section{Conclusion}

We have, for the first time to our knowledge, synthesized new 1,2,3-triazoles disubstituted in 4- and 5-positions by one benzyl and one aryl groups. We also evaluated these new compounds for potential antivascular and anticancer activities and found that several compounds presented interesting biological activities, e.g., rounding up of endothelial cells (at concentrations in the submicromolar range), inhibition of tubulin polymerization and cytotoxicity on B16 cancer cells (at concentrations in the low micromolar range). In silico docking studies of $\mathbf{1 1}$ and $\mathbf{1 9}$ within the active site of tubulin were also carried out in order to rationalize the inhibitory properties of these compounds and further understand their inhibition mechanism. In addition, the evaluation of compounds 11 and 19 in tumor bearing mice indicated modest in vivo anticancer activity.

\section{Experimental protocols}

\subsection{Synthesis}

Melting points were measured on a Köfler hot stage apparatus and are uncorrected. Mass spectra were recorded on a Waters ZQ 2000 system using electrospray ionization (ESI) or on a Waters LCT apparatus for High-resolution mass spectra (HRMS - ESI). Infrared spectra were obtained using an FT-IR Perkin-Elmer spectrometer as chloroform solutions or KBr discs. NMR spectra were recorded with a Bruker ACP 300 spectrometer at $300 \mathrm{MHz}$ for ${ }^{1} \mathrm{H}$ NMR and $75 \mathrm{MHz}$ for ${ }^{13} \mathrm{C}$ NMR. Chemical shifts are expressed as parts per million downfield from tetramethylsilane. Splitting patterns have been designated as follows: s (singlet), d (doublet), dd (doublet of doublet), m (multiplet), br. (broad signal). Coupling constants ( $J$ values) are listed in hertz $(\mathrm{Hz})$. Reactions were monitored by analytical thin layer chromatography and products were visualized by UV light. Merck Silica gel (230-400 Mesh ASTM) was used for column chromatography. Methanol and $\mathrm{CH}_{2} \mathrm{Cl}_{2}$ employed as eluents were distilled on a rotary evaporator prior to use. Dry THF was prepared by distillation from benzophenone/sodium.

\subsubsection{General procedure 1 for the synthesis of 2-aryl-1-nitroethenes 2 and 3.}


To a solution of the corresponding arylaldehyde in toluene were added nitromethane (11 equivalents), dimethylamine hydrochloride (4 equivalents) and potassium fluoride (0.15 equivalents). The flask was equipped with a Dean-Stark and the mixture was heated at reflux temperature until the disappearance of the arylaldehyde (usually noted after a reaction time of 4-5 hours). After being cooled at room temperature, the reaction mixture was evaporated under vacuum to eliminate the toluene, then diluted with water and extracted by $\mathrm{CH}_{2} \mathrm{Cl}_{2}(3 \mathrm{x})$. In some cases, a filtration over Celite surface was required in order to eliminate excess reagent or reaction residues prior to extraction. The organic phase was then washed with water, dried over $\mathrm{MgSO}_{4}$, filtered and concentrated under vacuum. Crude product was purified by chromatography on silica gel in order to afford the desired compound.

\subsubsection{2-(3-Hydroxy-4-methoxyophenyl)-1-nitroethene (2).}

General procedure 4.1.1. was applied to iso-vanillin (3-hydroxy-4-methoxybenzaldehyde) $(46.0 \mathrm{~g}, 0.30 \mathrm{~mol})$ with a reaction time of $3 \mathrm{~h}$. The crude product was purified by chromatography on silica gel $\left(\mathrm{CH}_{2} \mathrm{Cl}_{2} 100 \%\right)$ to provide the corresponding 2-aryl-1-nitroethene as an ocher-colored solid, which was afterwards recrystallized to afford bright orange crystals (30.0 g, $0.154 \mathrm{~mol}, 51 \%)$. Mp: $161-162{ }^{\circ} \mathrm{C}$ (heptane/benzene); ${ }^{1} \mathrm{H}-\mathrm{NMR}\left(300 \mathrm{MHz}, \mathrm{CDCl}_{3}\right.$ ): $\delta=3.97$ (s, 3H, $\mathrm{OCH}_{3}$ ), 5.73 (s, $1 \mathrm{H}, \mathrm{OH}), 6.90$ (d, $J=9.4 \mathrm{~Hz}, 1 \mathrm{H}, \mathrm{H}-5$ ') 7.07 (d, $\left.J=1.9 \mathrm{~Hz}, 1 \mathrm{H}, \mathrm{H}-2^{\prime}\right), 7.12$ (dd, $J_{l}=9.4 \mathrm{~Hz}, J_{2}=$ $1.9 \mathrm{~Hz}, 1 \mathrm{H}, \mathrm{H}-6$ '), 7.48 (d, $J=12.6 \mathrm{~Hz}, 1 \mathrm{H},=\mathrm{CH}-1), 7.92$ (d, $J=12.6 \mathrm{~Hz}, 1 \mathrm{H},=\mathrm{CH}-2) ;{ }^{13} \mathrm{C}-\mathrm{NMR}$ (75 MHz, DMSO): $\delta=56.5\left(\mathrm{CH}_{3}, \mathrm{OCH}_{3}\right), 112.6(\mathrm{CH}, \mathrm{C}-2$ '), $116.18(\mathrm{CH}, \mathrm{C}-5$ '), 124.4 (CH, C-6'), 128.7 (C, C-1'), 136.1 (CH, C-1), 140.4 (CH, C-2), 147.5 (C, C-3'), 152.3 (C, C-4'); IR (NaCl): v' $3542(\mathrm{OH}), 3023(=\mathrm{C}-\mathrm{H}), 1616(\mathrm{C}=\mathrm{C}), 1508\left(\mathrm{NO}_{2}\right.$ as $), 1340\left(\mathrm{NO}_{2} \mathrm{ss}\right), 1275(\mathrm{Ar}-\mathrm{O}), 1133(\mathrm{C}-\mathrm{O})$ $\mathrm{cm}^{-1}$; MS (ESI(-)): m/z 194 [M- $\left.{ }^{1} \mathrm{H}\right]$. Anal calcd for $\mathrm{C}_{9} \mathrm{H}_{9} \mathrm{NO}_{4}: \mathrm{C}: 55.39 ; \mathrm{H}: 4.65 ; \mathrm{N}: 7.18$. Found C: 55.51; H: 4.55; N: 7.29.

\subsubsection{2-(3,4,5-Trimethoxyphenyl)-1-nitroethene (3) [43].}

Mp: $124-125^{\circ} \mathrm{C}$ (isopropanol); ${ }^{1} \mathrm{H}-\mathrm{NMR}\left(300 \mathrm{MHz}, \mathrm{CDCl}_{3}\right): \delta=3.67$ (s, 9H, $\mathrm{OCH}_{3}-\mathrm{C}_{3}, \mathrm{OCH}_{3}-\mathrm{C}_{4}$, $\mathrm{OCH}_{3}-\mathrm{C}_{5}$ ), 6.75 (s, 2H, H-2', H-6') 7.53 (d, $\left.J=14.4 \mathrm{~Hz}, 1 \mathrm{H},=\mathrm{CH}-2\right), 7.93$ (d, $J=14.4 \mathrm{~Hz}, 1 \mathrm{H}$, $=\mathrm{CH}-1) ;{ }^{13} \mathrm{C}-\mathrm{NMR}\left(75 \mathrm{MHz}, \mathrm{CDCl}_{3}\right): \delta=: 56.3\left(\mathrm{CH}_{3}\right.$ x $\left.2, \mathrm{OCH}_{3}-\mathrm{C}_{3}, \mathrm{OCH}_{3}-\mathrm{C}_{5}{ }\right), 61.1\left(\mathrm{CH}_{3}, \mathrm{OCH}_{3}-\right.$ $\mathrm{C}_{4}$ ), 106.5 (CH x 2, C-2', C-6'), 125.3 (CH, C-2), 136.4 (C, C-1'), 139.3 (CH, C-1), 153.7 (C x 3, C-3', C-4', C-5'); IR (NaCl): v' 3021 (=C-H), 1633 (C=C), $1503\left(\mathrm{NO}_{2}\right.$ as), $1328\left(\mathrm{NO}_{2}\right.$ ss), 1244 (Ar-O), $1130(\mathrm{C}-\mathrm{O}) \mathrm{cm}^{-1}$; MS (ESI(+)): m/z $262[\mathrm{M}+\mathrm{Na}]^{+}$. Anal calcd for $\mathrm{C}_{11} \mathrm{H}_{13} \mathrm{NO}_{5}$ : C: 55.23; H: 5.48; N: 5.86. Found C: 55.42; H: 5.35; N: 5.97.

\subsubsection{General procedure 2 for the synthesis of 2-aryl-1-nitroethanes 4 and 5.}


To a flask containing the corresponding 2-aryl-1-nitroethene were added silica gel (2 grams per mmol of starting material), and $1.5 \mathrm{~mL}$ of 2-propanol and $8 \mathrm{~mL}$ of chloroform per gram of silica gel [53]. To this mixture were added $4 \mathrm{mmol}$ of $\mathrm{NaBH}_{4}$ per mmol of starting material in small amounts and the resulting mixture was allowed to stir at room temperature until the complete disappearance of the 2-aryl-1-nitroethene (usually noted after a reaction time of about 30 minutes). The reaction mixture was quenched with an aqueous solution of $0.1 \mathrm{~N} \mathrm{HCl}$, filtered to eliminate the silica gel and evaporated under vacuum to eliminate 2-propanol and chloroform. The resulting aqueous mixture was then extracted by $\mathrm{CH}_{2} \mathrm{Cl}_{2}(3 \mathrm{x})$. The organic phase was dried over $\mathrm{MgSO}_{4}$, filtered and concentrated under vacuum. Crude product was purified by chromatography on silica gel in order to afford the desired compound.

\subsubsection{2-(3-Hydroxy-4-methoxyphenyl)-1-nitroethane (4).}

General procedure 4.1.2. was applied to $2(10 \mathrm{~g}, 50.0 \mathrm{mmol})$ with a reaction time of 30 minutes. The crude product was purified by chromatography on silica gel $\left(\mathrm{CH}_{2} \mathrm{Cl}_{2}\right)$ to provide the corresponding 2-aryl-1-nitroethane as pale yellow needles (6.92 g, $35.1 \mathrm{mmol}, 68 \%) . \mathrm{Mp:} 52-53{ }^{\circ} \mathrm{C}$ (pentane); ${ }^{1} \mathrm{H}-\mathrm{NMR}\left(300 \mathrm{MHz}, \mathrm{CDCl}_{3}\right): \delta=: 3.21\left(\mathrm{t}, \mathrm{J}=7.7 \mathrm{~Hz}, 2 \mathrm{H}, \mathrm{CH}_{2}-2\right), 3.96\left(\mathrm{~s}, 3 \mathrm{H}, \mathrm{OCH}_{3}\right)$, $4.56\left(\mathrm{t}, \mathrm{J}=7.7 \mathrm{~Hz}, 2 \mathrm{H}, \mathrm{CH}_{2}-1\right), 5.62(\mathrm{~s}, 1 \mathrm{H}, \mathrm{OH}), 6.67$ (dd, $J_{1}=8.4 \mathrm{~Hz}, J_{2}=2.1 \mathrm{~Hz}, 1 \mathrm{H}, \mathrm{H}-6$ '), 6.77 $\left(\mathrm{d}, J=2.1 \mathrm{~Hz}, 1 \mathrm{H}, \mathrm{H}-2\right.$ '), $6.78\left(\mathrm{~d}, J=8.4 \mathrm{~Hz}, 1 \mathrm{H}, \mathrm{H}-5^{\prime}\right) ;{ }^{13} \mathrm{C}-\mathrm{NMR}\left(75 \mathrm{MHz}, \mathrm{CDCl}_{3}\right): \delta=33.9$ $\left(\mathrm{CH}_{2}, \mathrm{C}-2\right), 55.8\left(\mathrm{CH}_{3}, \mathrm{OCH}_{3}\right), 76.7\left(\mathrm{CH}_{2}, \mathrm{C}-1\right), 110.9\left(\mathrm{CH}, \mathrm{C}-5^{\prime}\right), 114.7\left(\mathrm{CH}, \mathrm{C}-2^{\prime}\right), 120.3(\mathrm{CH}, \mathrm{C}-$ 6'), 128.6 (C, C-1'), 145.8 (C, C-3'), 145.9 (C, C-4'); IR (NaCl): v' $3541(\mathrm{OH}), 1555\left(\mathrm{NO}_{2}\right.$ as), $1380\left(\mathrm{NO}_{2} \mathrm{ss}\right), 1273(\mathrm{Ar}-\mathrm{O}), 1029(\mathrm{C}-\mathrm{O}) \mathrm{cm}^{-1}$; MS (ESI(+)): m/z $220[\mathrm{M}+\mathrm{Na}]^{+} . \mathrm{C}_{9} \mathrm{H}_{11} \mathrm{NO}_{4}: \mathrm{C}$ : 54.82; H: 5.62; N: 7.10. Found C: 55.01; H: 5.59; N: 7.21.

\subsubsection{2-(3,4,5-Trimethoxyphenyl)-1-nitroethane (5).}

General procedure 4.1.2. was applied to $3(20 \mathrm{~g}, 83.6 \mathrm{mmol})$ with a reaction time of about 30 minutes. The crude product was purified by chromatography on silica gel $\left(\mathrm{CH}_{2} \mathrm{Cl}_{2} 100 \%\right)$ to provide the corresponding 2-aryl-1-nitroethane as white fluffy crystals (19.05 g, $79.0 \mathrm{mmol}, 94 \%)$. Mp: 84-85 ${ }^{\circ} \mathrm{C}$ (cyclohexane/benzene/); ${ }^{1} \mathrm{H}-\mathrm{NMR}\left(300 \mathrm{MHz}, \mathrm{CDCl}_{3}\right): \delta=3.24(\mathrm{t}, J=8.0 \mathrm{~Hz}, 2 \mathrm{H}$, $\left.\mathrm{CH}_{2}-2\right), 3.80$ (s, 3H, $\mathrm{OCH}_{3}-\mathrm{C}_{4}$ ) $), 3.85$ (s, 6H, $\mathrm{OCH}_{3}-\mathrm{C}_{3}, \mathrm{OCH}_{3}-\mathrm{C}_{5}$ ), 4.59 (t, J=8.0 Hz, 2H, $\mathrm{CH}_{2}-1$ ), 6.37 (s, 2H, H-2', H-6'); ${ }^{13} \mathrm{C}^{-N M R}\left(75 \mathrm{MHz}, \mathrm{CDCl}_{3}\right): \delta=33.8\left(\mathrm{CH}_{2}, \mathrm{C}-2\right), 56.0\left(\mathrm{CH}_{3}\right.$ x 2, $\mathrm{OCH}_{3}-$ $\left.\mathrm{C}_{3}, \mathrm{OCH}_{3}-\mathrm{C}_{5},\right), 60.7\left(\mathrm{CH}_{3}, \mathrm{OCH}_{3}-\mathrm{C}_{4}\right), 76.5\left(\mathrm{CH}_{2}, \mathrm{C}-1\right), 105.6(\mathrm{CH}$ x 2, C-2', C-6'), $131.4(\mathrm{C}, \mathrm{C}-$ 1'), 153.5 (C x 3, C-3', C-4', C-5'); IR ( $\mathrm{NaCl})$ : v' $1555\left(\mathrm{NO}_{2}\right.$ as), $1349\left(\mathrm{NO}_{2} \mathrm{ss}\right), 1240$ (Ar-O), 
$1131(\mathrm{C}-\mathrm{O}) \mathrm{cm}^{-1}$; MS (ESI(+)): m/z $264[\mathrm{M}+\mathrm{Na}]^{+} . \mathrm{C}_{11} \mathrm{H}_{15} \mathrm{NO}_{5}: \mathrm{C}: 54.77 ; \mathrm{H}: 6.27 ; \mathrm{N}: 5.81$. Found C: 54.89; H: 6.08; N: 5.90 .

\subsubsection{General procedure for the synthesis of 1,3-diaryl-2-nitropropenes 6 - 12, 23 - 25.}

To a solution of the corresponding 2-aryl-1-nitroethane in xylene were added dimethylamine hydrochloride ( 2 equivalents), potassium fluoride ( 0.2 equivalents) and the appropriate arylaldehyde (1 equivalent). The flask was equipped with a Dean-Stark and the mixture was heated at reflux temperature until the disappearance of the arylaldehyde (usually noted after a reaction time of 24 hours). After being cooled at room temperature, the reaction mixture was evaporated under vacuum to eliminate the xylene, then diluted with water and extracted by $\mathrm{CH}_{2} \mathrm{Cl}_{2}(3 \mathrm{x})$. The organic phase was then washed with water, dried over $\mathrm{MgSO}_{4}$, filtered and concentrated under vacuum. Crude product was purified by chromatography on silica gel in order to afford the desired compound [43]. Compounds 7, 8, 11, 12, 23, 24, and 25 are already described in ref [43].

\subsubsection{3-(3-Hydroxy-4-methoxyphenyl)-1-(3,4,5-trimethoxyphenyl)-2-nitropropene (6).}

General procedure 4.1.3. was performed with 3,4,5-trimethoxybenzaldehyde $(6.47 \mathrm{~g}, 33.0$ $\mathrm{mmol})$ and $4(5.91 \mathrm{~g}, 30.0 \mathrm{mmol})$ with a reaction time of $24 \mathrm{~h}$. The crude product was purified by chromatography on silica gel $\left(\mathrm{CH}_{2} \mathrm{Cl}_{2}\right.$ /acetone $\left.99 / 1\right)$ to provide the corresponding 1,2diarylnitroethene together with excess benzaldehyde, which was afterwards eliminated by treatment with Girard's T reagent [54]. The expected compound was obtained as a yellow solid and was then recrystallized from a mixture hexane/benzene to provide bright yellow crystals $(5.91 \mathrm{~g}, 15.7 \mathrm{mmol}$, 52\%). Mp: 95-96 ${ }^{\circ} \mathrm{C}$ (hexane/benzene); ${ }^{1} \mathrm{H}-\mathrm{NMR}\left(\mathbf{3 0 0} \mathbf{M H z}, \mathbf{C D C l}_{3}\right) \boldsymbol{\delta}=3.70\left(\mathrm{~s}, 3 \mathrm{H}, \mathrm{OCH}_{3}-\mathrm{C}_{4 "}\right)$, $3.82\left(\mathrm{~s}, 6 \mathrm{H}, \mathrm{OCH}_{3}-\mathrm{C}_{3 "}, \mathrm{OCH}_{3}-\mathrm{C}_{5}\right), 4.20\left(\mathrm{~s}, 2 \mathrm{H}, \mathrm{CH}_{2}-\mathrm{C}_{1}\right), 5.55(\mathrm{~s}, 1 \mathrm{H}, \mathrm{OH}), 6.66$ (s, 2H, H-2", H6"), 6.70 (s, 1H, H-2'), 6.80-6.81 (m, 2H, H-5', H-6'), 8.24 (s, 1H, H-2). ${ }^{13} \mathrm{C}-\mathrm{NMR}(75 \mathrm{MHz}$, $\left.\mathrm{CDCl}_{3}\right): \delta=32.6\left(\mathrm{CH}_{2}, \mathrm{CH}_{2}-\mathrm{Ar}\right), 56.4\left(\mathrm{CH}_{3} \times 3, \mathrm{OCH}_{3}-\mathrm{C}_{3}, \mathrm{OCH}_{3}-\mathrm{C}_{4}, \mathrm{OCH}_{3}-\mathrm{C}_{5}\right), 80.9\left(\mathrm{CH}_{3}\right.$, OCH3-C4"), 107.6 (CH x 2, C-2', C-6'), 110.9 (CH, C-6”), 114.1 (CH, C-5”), 118.7 (CH, C-2”), 127.2 (CH, C-2), 129.4 (C, C-1'), 136.0 (C, C-1”), 140.0 (C, C-1), 145.5 (C, C-3”), 145.9 (C, C-4”), 148.7 (C, C-4'), 153.7 (C x 2, C-3', C-5'); IR (NaCl): v' 3541 (OH), 3023 (=C-H), 1592 (C=C), $1554\left(\mathrm{NO}_{2}\right.$ as), $1379\left(\mathrm{NO}_{2}\right.$ ss), $1272(\mathrm{Ar}-\mathrm{O}), 1130(\mathrm{C}-\mathrm{O}) \mathrm{cm}^{-1} ; \mathrm{MS}(\mathrm{ESI}(+)): \mathrm{m} / \mathrm{z} 398$ [M+Na] $\mathrm{C}_{19} \mathrm{H}_{21} \mathrm{NO}_{7}: \mathrm{C}: 60.79 ; \mathrm{H}: 5.64 ; \mathrm{N}: 3.73$. Found C: 60.84; H: 5.65; N: 3.78.

\subsubsection{1-(4-Methoxy-3-nitrophenyl)-3-(3,4,5-trimethoxyphenyl)-2-nitropropene (9).}


General procedure 4.1.3. was performed with 4-methoxy-3-nitrobenzaldehyde $(5.80 \mathrm{~g}$, $32.0 \mathrm{mmol})$ and $5(7.60 \mathrm{~g}, 31.5 \mathrm{mmol})$ with a reaction time of $24 \mathrm{~h}$. The crude product was purified by chromatography on silica gel $\left(\mathrm{CH}_{2} \mathrm{Cl}_{2}\right.$ /acetone $\left.99 / 1\right)$ to provide the corresponding 1,2diarylnitroethene as a yellow solid, which was afterwards recrystallized to provide bright yellow crystals (6.78 g, $16.8 \mathrm{mmol}, 53 \%$ ). Mp: 158-159 ${ }^{\circ} \mathrm{C}$ (heptane/benzene); ${ }^{1} \mathrm{H}-\mathrm{NMR}$ (300 MHz, $\left.\mathrm{CDCl}_{3}\right): \delta=3.80\left(\mathrm{~s}, 6 \mathrm{H}, \mathrm{OCH}_{3}-\mathrm{C}_{3}, \mathrm{OCH}_{3}-\mathrm{C}_{5}\right.$ ), $3.82\left(\mathrm{~s}, 3 \mathrm{H}, \mathrm{OCH}_{3}-\mathrm{C}_{4}{ }^{\prime}\right), 4.01\left(\mathrm{~s}, 3 \mathrm{H}, \mathrm{OCH}_{3}-\mathrm{C}_{4}{ }^{\prime}\right)$, 4.21 (s, 2H, CH $-\mathrm{Ar}$ ), 6.39 (s, 2H, H-2', H-6'), 7.15 (d, J = 9.1 Hz, 1H, H-5”), 7.62 (dd, $J_{l}=9.1 \mathrm{~Hz}$, $\left.J_{2}=2.0 \mathrm{~Hz}, 1 \mathrm{H}, \mathrm{H}-6 ”\right), 8.01$ (d, $\left.J=2.0 \mathrm{~Hz}, 1 \mathrm{H}, \mathrm{H}-2 ”\right), 8.26$ (s, 1H, =CH-2); ${ }^{13} \mathrm{C}-\mathrm{NMR}(75 \mathrm{MHz}$, $\left.\mathrm{CDCl}_{3}\right): \delta=33.1\left(\mathrm{CH}_{2}, \mathrm{CH}_{2}-\mathrm{Ar}\right), 56.1\left(\mathrm{CH}_{3} \mathrm{x} 2, \mathrm{OCH}_{3}-\mathrm{C}_{3}, \mathrm{OCH}_{3}-\mathrm{C}_{5}\right), 56.8\left(\mathrm{CH}_{3}, \mathrm{OCH}_{3}-\mathrm{C}_{4}{ }^{\prime}\right), 60.8$ $\left(\mathrm{CH}_{3}, \mathrm{OCH}_{3}-\mathrm{C}_{4}\right.$ ") 104.6 (CH x 2, C-2', C-6'), 114.3 (CH, C-5"), 121.2 (C, C-1"), 124.2 (CH, C2”), 131.1 (CH, C-6”), 132.6 (C, C-1'), 135.6 (CH, C-2), 137.2 (C, C-3”), 149.8 (C, C-1), 153.7 (C x 3, C-3', C-4', C-5'), 154.3 (C, C-4”); IR (NaCl): v' 3021 (=C-H), 1592 (C=C), $1535\left(\mathrm{NO}_{2}\right.$ as), $1329\left(\mathrm{NO}_{2} \mathrm{ss}\right), 1240(\mathrm{Ar}-\mathrm{O}), 1130(\mathrm{C}-\mathrm{O}) \mathrm{cm}^{-1}$; MS (ESI(+)): m/z $427[\mathrm{M}+\mathrm{Na}]^{+} . \mathrm{C}_{19} \mathrm{H}_{20} \mathrm{~N}_{2} \mathrm{O}_{8}: \mathrm{C}$ : 56.43; H: 4.99; N: 6.93. Found C: 56.54; H: 5.01; N: 7.02.

\subsubsection{1-(3-Fluoro-4-methoxyphenyl)-3-(3,4,5-trimethoxyphenyl)-2-nitropropene (10).}

General procedure 4.1.3. was performed with 3-fluoro-4-methoxybenzaldehyde (2.50 g, 16.2 $\mathrm{mmol})$ and 5 (3.50 g, $14.6 \mathrm{mmol})$ with a reaction time of $24 \mathrm{~h}$. The crude product was purified by chromatography on silica gel $\left(\mathrm{CH}_{2} \mathrm{Cl}_{2}\right.$ /acetone 99/1) to provide the corresponding 1,2diarylnitroethene as an orange solid, which was afterwards recrystallized to afford bright ochercolored fine crystals (1.77 g, $4.7 \mathrm{mmol}, 32 \%)$. Mp: 126-128 ${ }^{\circ} \mathrm{C}$ (heptane/benzene); ${ }^{1} \mathrm{H}-\mathrm{NMR}$ (300 $\left.\mathrm{MHz}, \mathrm{CDCl}_{3}\right): \delta=3.80\left(\mathrm{~s}, 6 \mathrm{H}, \mathrm{OCH}_{3}-\mathrm{C}_{3}, \mathrm{OCH}_{3}-\mathrm{C}_{5}\right.$ ) $), 3.83$ (s, $3 \mathrm{H}, \mathrm{OCH}_{3}-\mathrm{C}_{4}$ ) $), 3.93\left(\mathrm{~s}, 3 \mathrm{H}, \mathrm{OCH}_{3^{-}}\right.$ $\mathrm{C}_{4}$ '), 4.22 (s, 2H, $\mathrm{CH}_{2}$-Ar), 6.39 (s, 2H, H-2', H-6'), 6.98-7.03 (m, 1H, H-5”), 7.23-7.30 (m, 2H, H2", H-6"), 8.23 (s, 1H, =CH-2); ${ }^{13} \mathrm{C}-\mathrm{NMR}\left(75 \mathrm{MHz}, \mathrm{CDCl}_{3}\right): \delta=33.1\left(\mathrm{CH}_{2}, \mathrm{CH}_{2}-\mathrm{Ar}\right), 56.1\left(\mathrm{CH}_{3} \mathrm{x}\right.$ 2, $\left.\mathrm{OCH}_{3}-\mathrm{C}_{3}, \mathrm{OCH}_{3}-\mathrm{C}_{5}{ }^{\prime}\right), 56.3\left(\mathrm{CH}_{3}, \mathrm{OCH}_{3}-\mathrm{C}_{4}{ }^{\prime}\right), 60.8\left(\mathrm{CH}_{3}, \mathrm{OCH}_{3}-\mathrm{C}_{4}{ }^{\prime \prime}\right), 104.5$ (CH x 2, C-2', C-6'), 113.5 (CH, $J=7.2 \mathrm{~Hz}, \mathrm{C}-5 ”), 117.4$ (CH, $J=20.1 \mathrm{~Hz}, \mathrm{C}-2 ”), 124.5$ (C, $J=7.2 \mathrm{~Hz}, \mathrm{C}-1$ "), 127.3 (CH, C-2), 131.5 (CH, C-6”), 134.6 (C, C-1'), 137.0 (C, C-1), 149.8 (C, J = 20.1 Hz, C-4”), 152.2 (C, $J=246.8$ Hz, C-3”), 153.6 (C x 3, C-3', C-4', C-5'); IR (NaCl): v' 3022 (=C-H), 1613 (C=C), $1513\left(\mathrm{NO}_{2}\right.$ as), $1329\left(\mathrm{NO}_{2}\right.$ ss), $1240(\mathrm{Ar}-\mathrm{O}), 1131(\mathrm{C}-\mathrm{O}) \mathrm{cm}^{-1} ; \mathrm{MS}(\mathrm{ESI}(+)): \mathrm{m} / \mathrm{z} 400[\mathrm{M}+\mathrm{Na}]^{+}$. $\mathrm{C}_{19} \mathrm{H}_{20} \mathrm{FNO}_{6}: \mathrm{C}: 60.47 ; \mathrm{H}: 5.34 ; \mathrm{N}: 3.71$. Found C: 60.66; H: 5.29; N: 3.67.

\subsubsection{General procedure for the synthesis of 4-benzyl-5-phenylriazoles 14 - 22}


To a solution of the corresponding benzylphenylnitroethene in DMSO (minimum volume: approximately $10 \mathrm{~mL}$ for $3 \mathrm{mmol}$ ) was added $\mathrm{NaN}_{3}$ (2 equivalents) [42]. The resulting mixture, which acquired a dark red color right after the addition, was allowed to stir at $85{ }^{\circ} \mathrm{C}$ under argon atmosphere until complete conversion of the starting material (usually noted after a reaction time of 15 hours). After being cooled at room temperature, the reaction mixture was diluted with water and then extracted by $\mathrm{CH}_{2} \mathrm{Cl}_{2}(4 \mathrm{x})$. The organic phase was dried over $\mathrm{MgSO}_{4}$, filtered and concentrated under vacuum. Crude product was purified by chromatography on silica gel. In order to eliminate remaining DMSO, the evaporated fractions containing the desired compound were dissolved in ether and washed with water (3x), dried over $\mathrm{MgSO}_{4}$, filtered and then concentrated under reduced pressure.

\subsubsection{4-(3-Hydroxy-4-methoxybenzyl)-5-(3,4,5-trimethoxyphenyl)-1,2,3-triazole (14).}

General procedure 4.1.4. was applied to $6(1.13 \mathrm{~g}, 3.0 \mathrm{mmol})$ with a reaction time of $12 \mathrm{~h}$. The crude product was purified by chromatography on silica gel $\left(\mathrm{CH}_{2} \mathrm{Cl}_{2} / \mathrm{MeOH} 95 / 5\right)$ and then treated to eliminate remaining DMSO according to general procedure 4 to provide the expected compound as a white foamy solid $(0.94 \mathrm{~g}, 2.53 \mathrm{mmol}, 84 \%)$. Mp: 82-83 ${ }^{\circ} \mathrm{C}$ (heptane/benzene); ${ }^{1} \mathrm{H}-$ NMR (300 MHz, $\left.\mathrm{CDCl}_{3}\right): \delta=3.77\left(\mathrm{~s}, 6 \mathrm{H}, \mathrm{OCH}_{3}-\mathrm{C}_{3}, \mathrm{OCH}_{3}-\mathrm{C}_{5}\right.$ ), $3.64\left(\mathrm{~s}, 3 \mathrm{H}, \mathrm{OCH}_{3}-\mathrm{C}_{4}\right.$ ) $), 3.66(\mathrm{~s}$, $3 \mathrm{H}, \mathrm{OCH}_{3}-\mathrm{C}_{4}$ "), 4.18 (s, 2H, $\mathrm{CH}_{2}$ ), 5.80 (bs, $\left.1 \mathrm{H}, \mathrm{OH}\right), 6.65$ (dd, $J_{l}=8.5 \mathrm{~Hz}, J_{2}=2.0 \mathrm{~Hz}, 1 \mathrm{H}, \mathrm{H}-$ 6"'), 6.76 (d, $J=8.5 \mathrm{~Hz}, 1 \mathrm{H}, \mathrm{H}-5 "$ "), 6.78 (d, $J=2.0 \mathrm{~Hz}, 1 \mathrm{H}, \mathrm{H}-2$ "), 6.81 (s, 2H, H-2', H-6'); ${ }^{13} \mathrm{C}-$ NMR (75 MHz, $\left.\mathrm{CDCl}_{3}\right): \delta=30.6\left(\mathrm{CH}_{2}, \mathrm{CH}_{2}-\mathrm{Ar}\right), 56.1\left(\mathrm{CH}_{3} \mathrm{x} 3, \mathrm{OCH}_{3}-\mathrm{C}_{3}, \mathrm{OCH}_{3}-\mathrm{C}_{4}, \mathrm{OCH}_{3}-\mathrm{C}_{5}\right.$ ), $60.9\left(\mathrm{CH}_{3}, \mathrm{OCH}_{3}-\mathrm{C}_{4}\right.$ "), 104.8 ( $\mathrm{CH} \times$ x 2, C-2', C-6'), 111.0 (CH, C-5”), 114.8 (CH, C-2”), 119.7 (CH, C-6”), 125.9 (C, C-5), 131.3 (C, C-1'), 138.0 (C, C-4), 145.5 (C, C-3”), 146.0 (C, C-4”), 153.4 (C x 3, C-3', C-4', C-5'); IR (NaCl): v' $3541(\mathrm{OH}), 3009$ (NH), 1590 (C=C), 1239 (Ar-O), 1129 (C-O) $\mathrm{cm}^{-1}$; HRMS (ESI): $\mathrm{m} / \mathrm{z} 372.1577[\mathrm{M}+\mathrm{H}]^{+}, \mathrm{C}_{19} \mathrm{H}_{22} \mathrm{~N}_{3} \mathrm{O}_{5}$ requires 372.1559

\subsubsection{5-(Benzo-[1,3]-dioxol-5-yl)-4-(3,4,5-trimethoxybenzyl)-1,2,3-triazole (15).}

General procedure 4.1.4. was applied to 2-(benzo-[1,3]-dioxol-5-yl)-1-(3,4,5trimethoxybenzyl)-1-nitroethene $(7)(1.00 \mathrm{~g}, 2.7 \mathrm{mmol})$ with a reaction time of $6 \mathrm{~h}$. The crude product was purified by chromatography on silica gel $\left(\mathrm{CH}_{2} \mathrm{Cl}_{2} / \mathrm{MeOH} 95 / 5\right)$ and then treated to eliminate remaining DMSO according to general procedure 4.1.4 to provide the expected compound as a light brown foamy solid $(0.96 \mathrm{~g}, 2.60 \mathrm{mmol}, 96 \%)$. Mp: $153-154{ }^{\circ} \mathrm{C}$ (heptane/benzene); ${ }^{1} \mathrm{H}-$ NMR (300 MHz, $\left.\mathrm{CDCl}_{3}\right): \delta=3.76\left(\mathrm{~s}, 6 \mathrm{H}, \mathrm{OCH}_{3}-\mathrm{C}_{3}, \mathrm{OCH}_{3}-\mathrm{C}_{5}\right.$ ) $, 3.81\left(\mathrm{~s}, 3 \mathrm{H}, \mathrm{OCH}_{3}-\mathrm{C}_{4}\right.$ ) $), 4.14(\mathrm{~s}$, 2H, $\mathrm{CH}_{2}$-Ar), 5.99 (s, 2H, $\mathrm{CH}_{2}-\mathrm{O}$ ), 6.39 (s, 2H, H-2', H-6'), 6.85 (d, J = 7.7 Hz, 1H, H-7'), 7.06 (d, 
$J=2.1 \mathrm{~Hz}, 1 \mathrm{H}, \mathrm{H}-4 ”), 7.09$ (dd, $\left.J_{1}=7.7 \mathrm{~Hz}, J_{2}=2.1 \mathrm{~Hz}, 1 \mathrm{H}, \mathrm{H}-6 "\right) ;{ }^{13} \mathrm{C}-\mathrm{NMR}(75 \mathrm{MHz}$, $\left.\mathrm{CDCl}_{3}\right): \delta=31.3\left(\mathrm{CH}_{2}, \mathrm{CH}_{2}-\mathrm{Ar}\right), 55.9\left(\mathrm{CH}_{3}\right.$ x $\left.2, \mathrm{OCH}_{3}-\mathrm{C}_{3}, \mathrm{OCH}_{3}-\mathrm{C}_{5},\right), 60.9\left(\mathrm{CH}_{3}, \mathrm{OCH}_{3}-\mathrm{C}_{4}{ }^{\prime}\right)$, $101.3\left(\mathrm{CH}_{2}, \mathrm{CH}_{2}-\mathrm{O}\right), 105.5$ (CH x 2, C-2', C-6'), 108.3 (CH, C-4”), 108.6 (CH, C-7”), 121.6 (CH, C-6”), 124.0 (C, C-5”), 134.1 (C, C-1'), 136.4 (C, C-5), 142.0 (C, C-4), 147.7 (C, C-3”a), 147.9 (C, C-7”'a), 153.2 (C x 3, C-3', C-4', C-5'); IR (NaCl): v' 3009 (NH), 1592 (C=C), 1240 (Ar-O), 1130 (C-O) $\mathrm{cm}^{-1}$; HRMS (ESI): $\mathrm{m} / \mathrm{z} 370.1414[\mathrm{M}+\mathrm{H}]^{+}, \mathrm{C}_{19} \mathrm{H}_{20} \mathrm{~N}_{3} \mathrm{O}_{5}$ requires 370.1403

\subsubsection{5-(2,4-Dichlorophenyl)-4-(3,4,5-trimethoxybenzyl)-1,2,3-triazole (16).}

General procedure 4.1.4. was applied to 2-(2,4-dichlorophenyl)-1-(3,4,5-trimethoxybenzyl)1-nitroethene $(\mathbf{8})(1.00 \mathrm{~g}, 2.5 \mathrm{mmol})$ with a reaction time of $12 \mathrm{~h}$. The crude product was purified by chromatography on silica gel $\left(\mathrm{CH}_{2} \mathrm{Cl}_{2} / \mathrm{MeOH} 95 / 5\right)$ and then treated to eliminate remaining DMSO according to general procedure 4 to provide the expected compound as an orange solid $(0.96 \mathrm{~g}, 2.43$ mmol, 97\%). Mp: $127-128{ }^{\circ} \mathrm{C}$ (heptane/benzene); ${ }^{1} \mathrm{H}-\mathrm{NMR}\left(300 \mathrm{MHz}, \mathrm{CDCl}_{3}\right): \delta=3.74(\mathrm{~s}, 6 \mathrm{H}$, $\mathrm{OCH}_{3}-\mathrm{C}_{3}, \mathrm{OCH}_{3}-\mathrm{C}_{5}$ ), 3.76 (s, 3H, $\mathrm{OCH}_{3}-\mathrm{C}_{4}$ ) $), 3.98$ (s, 2H, $\left.\mathrm{CH}_{2}\right), 6.25$ (s, 2H, H-2', H-6'), 7.18 (d, $J=9.1 \mathrm{~Hz}, 1 \mathrm{H}, \mathrm{H}-6 ”), 7.25$ (dd, $\left.J_{1}=9.1 \mathrm{~Hz}, J_{2}=1.8 \mathrm{~Hz}, 1 \mathrm{H}, \mathrm{H}-5 ”\right), 7.48$ (d, $J=1.8 \mathrm{~Hz}, 1 \mathrm{H}, \mathrm{H}-3$ "); ${ }^{13} \mathrm{C}-\mathrm{NMR}\left(75 \mathrm{MHz}, \mathrm{CDCl}_{3}\right): \delta=31.2\left(\mathrm{CH}_{2}, \mathrm{CH}_{2}-\mathrm{Ar}\right), 56.8\left(\mathrm{CH}_{3}\right.$ x 2, $\left.\mathrm{OCH}_{3}-\mathrm{C}_{3}, \mathrm{OCH}_{3}-\mathrm{C}_{5}\right), 60.9$ $\left(\mathrm{CH}_{3}, \mathrm{OCH}_{3}-\mathrm{C}_{4}\right.$ ) $), 105.9$ (CH x 2, C-2', C-6'), 127.1 (CH, C-3”), 128.3 (C, C-5), 129.6 (CH, C-6”), 132.7 (CH, C-5”), 133.6 (C, C-4), 134.7 (C, C-1"), 135.5 (C, C-2”), 136.3 (C, C-4”), 152.0 (C x 3, C-3', C-4', C-5'); IR (NaCl): v' 3009 (NH), 1593 (C=C), 1239 (Ar-O), 1121 (C-O), 754 (C-Cl) cm ${ }^{1}$; HRMS (ESI): m/z $370.1414[\mathrm{M}+\mathrm{H}]^{+}, \mathrm{C}_{18} \mathrm{H}_{18}{ }^{35} \mathrm{Cl}_{2} \mathrm{~N}_{3} \mathrm{O}_{3}$ requires 394.0730.

\subsubsection{5-(4-Methoxy-3-nitrophenyl)-4-(3,4,5-trimethoxybenzyl)-1,2,3-triazole (17).}

General procedure 4.1.4. was applied to $9(1.68 \mathrm{~g}, 4.15 \mathrm{mmol})$ with a reaction time of $6 \mathrm{~h}$. The crude product was purified by chromatography on silica gel, using a gradient of $\mathrm{MeOH}$ in $\mathrm{CH}_{2} \mathrm{Cl}_{2}$ from $99 / 1$ to $95 / 5$ as eluent, and then treated to eliminate remaining DMSO according to general procedure 4 to provide the expected compound as a yellow foamy solid, which was afterwards recrystallized to afford bright orange fine crystals $(0.60 \mathrm{~g}, 1.5 \mathrm{mmol}, 36 \%)$. Mp: 165-166 ${ }^{\circ} \mathrm{C}$ (benzene/acetonitrile); ${ }^{1} \mathrm{H}-\mathrm{NMR}\left(300 \mathrm{MHz}, \mathrm{CDCl}_{3}\right): \delta=3.80\left(\mathrm{~s}, 6 \mathrm{H}, \mathrm{OCH}_{3}-\mathrm{C}_{3}, \mathrm{OCH}_{3}-\mathrm{C}_{5}\right.$ ), 3.82 (s, 3H, $\mathrm{OCH}_{3}-\mathrm{C}_{4}$ ), 4.00 (s, 3H, $\left.\mathrm{OCH}_{3}-\mathrm{C}_{4}{ }^{\prime}\right), 4.19$ (s, 2H, $\mathrm{CH}_{2}-\mathrm{Ar}$ ), 6.44 (s, 2H, H-2', H-6'), 7.14 (d, $J=9.4 \mathrm{~Hz}, 1 \mathrm{H}, \mathrm{H}-5 ”), 7.88$ (dd, $\left.J_{l}=9.4 \mathrm{~Hz}, J_{2}=1.5 \mathrm{~Hz}, 1 \mathrm{H}, \mathrm{H}-6 ”\right), 8.13$ (d, $J=1.5 \mathrm{~Hz}, 1 \mathrm{H}, \mathrm{H}-2$ "); ${ }^{13} \mathrm{C}-\mathrm{NMR}\left(75 \mathrm{MHz}, \mathrm{CDCl}_{3}\right): \delta=31.6\left(\mathrm{CH}_{2}, \mathrm{CH}_{2}-\mathrm{Ar}\right), 56.1\left(\mathrm{CH}_{3}\right.$ x $\left.2, \mathrm{OCH}_{3}-\mathrm{C}_{3}, \mathrm{OCH}_{3}-\mathrm{C}_{5},\right), 56.7$ $\left(\mathrm{CH}_{3}, \mathrm{OCH}_{3}-\mathrm{C}_{4}{ }^{\prime}\right), 60.9\left(\mathrm{CH}_{3}, \mathrm{OCH}_{3}-\mathrm{C}_{4}{ }^{\prime}\right), 105.5$ (CH x 2, C-2', C-6'), 113.9 (CH, C-5”), 123.3 (C, C-1”), 124.6 (CH, C-2”), 132.9 (C, C-5), 133.2 (CH, C-6” + C, C-1'), 136.8 (C, C-3”), 139.5 (C, C- 
4), 152.9 (C, C-4”), 153.5 (C x 3, C-3', C-4', C-5'); IR (NaCl): v' 3017 (NH), 1592 (C=C), 1508 $\left(\mathrm{NO}_{2}\right.$ as), $1353\left(\mathrm{NO}_{2} \mathrm{ss}\right), 1239$ (Ar-O), 1129 (C-O) cm ${ }^{-1}$; HRMS (ESI): m/z $401.1470[\mathrm{M}+\mathrm{H}]^{+}$, $\mathrm{C}_{19} \mathrm{H}_{21} \mathrm{~N}_{4} \mathrm{O}_{6}$ requires 401.1461 .

4.1.4.5. 5-(3-Fluoro-4-methoxyphenyl)-4-(3,4,5-trimethoxybenzyl)-1,2,3-triazole (18).

General procedure 4.1.4. was applied to $10(1.00 \mathrm{~g}, 2.63 \mathrm{mmol})$ with a reaction time of $12 \mathrm{~h}$. The crude product was then purified by chromatography on silica gel $\left(\mathrm{CH}_{2} \mathrm{Cl}_{2} / \mathrm{MeOH} 99.5 / 0.5\right)$ and then treated to eliminate remaining DMSO according to general procedure 4 to provide the expected compound as a light brown solid $(0.53 \mathrm{~g}, 1.42 \mathrm{mmol}, 54 \%) . \mathrm{Mp}: 115-117^{\circ} \mathrm{C}$ (heptane/benzene); ${ }^{1} \mathrm{H}-$ NMR (300 MHz, $\mathrm{CDCl}_{3}$ ): $\delta=3.74\left(\mathrm{~s}, 6 \mathrm{H}, \mathrm{OCH}_{3}-\mathrm{C}_{3}, \mathrm{OCH}_{3}-\mathrm{C}_{5}\right.$ ), 3.79 (s, 3H, $\left.\mathrm{OCH}_{3}-\mathrm{C}_{4}{ }^{\prime}\right), 3.89$ (s, $\left.3 \mathrm{H}, \mathrm{OCH}_{3}-\mathrm{C}_{4}{ }^{\prime \prime}\right), 4.14$ (s, 2H, $\mathrm{CH}_{2}-\mathrm{Ar}$ ), 6.38 (s, 2H, H-2', H-6'), 6.94-6.99 (m, 1H, H-5”), 7.30-7.39 (m, 2H, H-2", H-6"); ${ }^{13} \mathrm{C}-\mathrm{NMR}\left(75 \mathrm{MHz}, \mathrm{CDCl}_{3}\right): \delta=31.4\left(\mathrm{CH}_{2}, \mathrm{CH}_{2}-\mathrm{Ar}\right), 56.0\left(\mathrm{CH}_{3}\right.$ x 2, $\mathrm{OCH}_{3}-$ $\left.\mathrm{C}_{3}, \mathrm{OCH}_{3}-\mathrm{C}_{5}{ }^{\prime}\right), 56.3\left(\mathrm{CH}_{3}, \mathrm{OCH}_{3}-\mathrm{C}_{4}{ }^{\prime}\right), 60.8\left(\mathrm{CH}_{3}, \mathrm{OCH}_{3}-\mathrm{C}_{4},\right), 105.5\left(\mathrm{CH} \times 2, \mathrm{C}-2^{\prime}, \mathrm{C}^{\prime} 6^{\prime}\right), 113.5$ $(\mathrm{CH}, J=6.9 \mathrm{~Hz}, \mathrm{C}-5$ ”), 115.5 (CH, $J=20.3 \mathrm{~Hz}, \mathrm{C}-2$ ”), 123.4 (C, $J=6.9 \mathrm{~Hz}, \mathrm{C}-1$ "), 123.6 (CH, $J=$ 3.7 Hz, C-6”), 133.7 (C, C-1'), 136.6 (C x 2, C-4, C-5), 147.7 (C, $J=20.3$ Hz, C-4”), 152.3 (C, J = $244.1 \mathrm{~Hz}, \mathrm{C}-3$ ”), 153.3 (C x 3, C-3', C-4', C-5'); IR (NaCl): v' 3011 (NH), 1591 (C=C), 1239 (ArO), $1130(\mathrm{C}-\mathrm{O}) \mathrm{cm}^{-1}$; HRMS (ESI): m/z $374.1527[\mathrm{M}+\mathrm{H}]^{+}, \mathrm{C}_{19} \mathrm{H}_{21} \mathrm{FN}_{3} \mathrm{O}_{4}$ requires 374.1516.

\subsubsection{4-(3,4,5-Trimethoxybenzyl)-5-(3-hydroxy-4-methoxyphenyl)-1,2,3-triazole (19).}

General procedure 4.1.4. was applied to $11(1.13 \mathrm{~g}, 3.0 \mathrm{mmol})$ with a reaction time of $12 \mathrm{~h}$. The crude product was purified by chromatography on silica gel $\left(\mathrm{CH}_{2} \mathrm{Cl}_{2} / \mathrm{MeOH} 95 / 5\right)$ and then treated to eliminate remaining DMSO according to general procedure 4 to provide the expected compound as a whitish foamy solid $(0.94 \mathrm{~g}, 2.53 \mathrm{mmol}, 84 \%) . \mathrm{Mp}: 82-83{ }^{\circ} \mathrm{C}$ (heptane/benzene); ${ }^{1} \mathrm{H}-\mathrm{NMR}\left(300 \mathrm{MHz}, \mathrm{CDCl}_{3}\right): \delta=3.75\left(\mathrm{~s}, 6 \mathrm{H}, \mathrm{OCH}_{3}-\mathrm{C}_{3}, \mathrm{OCH}_{3}-\mathrm{C}_{5}\right.$ ) $, 3.79\left(\mathrm{~s}, 3 \mathrm{H}, \mathrm{OCH}_{3}-\mathrm{C}_{4}{ }^{\prime}\right), 3.90$ (s, 3H, $\left.\mathrm{OCH}_{3}-\mathrm{C}_{4}{ }^{\prime}\right), 4.17$ (s, 2H, $\mathrm{CH}_{2}$ ), 5.35 (br. s, 1H, OH), 6.43 (s, 2H, H-2', H-6'); 6.88 (d, J= $8.3 \mathrm{~Hz}, 1 \mathrm{H}, \mathrm{H}-5$ ”), 7.11 (dd, $\left.J_{1}=8.3 \mathrm{~Hz}, J_{2}=1.2 \mathrm{~Hz}, 1 \mathrm{H}, \mathrm{H}-6 ”\right), 7.22$ (br. s, $\left.1 \mathrm{H}, \mathrm{H}-2{ }^{\prime \prime}\right) ;{ }^{13} \mathrm{C}-\mathrm{NMR}$ $\left(75 \mathrm{MHz}, \mathrm{CDCl}_{3}\right): \delta=32.0\left(\mathrm{CH}_{2}, \mathrm{CH}_{2}-\mathrm{Ar}\right), 56.5\left(\mathrm{CH}_{3}\right.$ x 3, $\left.\mathrm{OCH}_{3}-\mathrm{C}_{3}, \mathrm{OCH}_{3}-\mathrm{C}_{4}, \mathrm{OCH}_{3}-\mathrm{C}_{5}{ }^{\prime}\right), 60.8$ $\left(\mathrm{CH}_{3}, \mathrm{OCH}_{3}-\mathrm{C}_{4}\right.$ '), 106.4 (CH x 2, C-2', C-6'), 113.2 (CH, C-5”), 115.4 (CH, C-2”), 119.1 (CH, C6”), 124.8 (C, C-5), 135.5 (C, C-1'), 136.6 (C, C-1'”), 142.7 (C, C-3'’), 144.6 (C, C-4), 147.5 (C, C4”), 153.6 (C x 2, C-3', C-5'); IR (NaCl): v’ 3541 (OH), 3009 (NH), 1590 (C=C), 1239 (Ar-O), 1129 (C-O) $\mathrm{cm}^{-1}$; HRMS (ESI): m/z $372.1578[\mathrm{M}+\mathrm{H}]^{+}, \mathrm{C}_{19} \mathrm{H}_{22} \mathrm{~N}_{3} \mathrm{O}_{5}$ requires 372.1559 
General procedure 4.1.4. was applied to $12(1.13 \mathrm{~g}, 3.0 \mathrm{mmol})$ with a reaction time of $14 \mathrm{~h}$. The crude product was purified by chromatography on silica gel $\left(\mathrm{CH}_{2} \mathrm{Cl}_{2} / \mathrm{MeOH} 95 / 5\right)$ and then treated to eliminate remaining DMSO according to general procedure 4 to provide the expected compound as a whitish foamy solid (0.91 g, $2.45 \mathrm{mmol}, 81 \%)$. Mp: 91-93 ${ }^{\circ} \mathrm{C}$ (heptane/benzene); ${ }^{1} \mathrm{H}-\mathrm{NMR}$ (300 $\left.\mathrm{MHz}, \mathrm{CDCl}_{3}\right): \delta=3.68\left(\mathrm{~s}, 6 \mathrm{H}, \mathrm{OCH}_{3}-\mathrm{C}_{3}, \mathrm{OCH}_{3}-\mathrm{C}_{5}\right.$ ), 3.69 (s, 3H, $\left.\mathrm{OCH}_{3}-\mathrm{C}_{4}{ }^{\prime}\right), 3.77\left(\mathrm{~s}, 3 \mathrm{H}, \mathrm{OCH}_{3}-\right.$ $\mathrm{C}_{4}{ }^{\prime}$ ), 4.14 (s, 2H, $\mathrm{CH}_{2}$ ), 5.77 (br. s, 1H, OH), 6.36 (s, 2H, H-2', H-6'); 6.90 (d, J = 8.0 Hz, 1H, H5"), 7.02 (d, $J=1.7 \mathrm{~Hz}, 1 \mathrm{H}, \mathrm{H}-2$ '”), 7.22 (dd, $\left.J_{1}=8.0 \mathrm{~Hz}, J_{2}=1.7 \mathrm{~Hz}, 1 \mathrm{H}, \mathrm{H}-6 "\right)$ ) ${ }^{13} \mathrm{C}-\mathrm{NMR}(75$ $\left.\mathrm{MHz}, \mathrm{CDCl}_{3}\right): \delta=31.7\left(\mathrm{CH}_{2}, \mathrm{CH}_{2}-\mathrm{Ar}\right), 56.2\left(\mathrm{CH}_{3}, \mathrm{OCH}_{3}-\mathrm{C}_{4}\right), 56.4\left(\mathrm{CH}_{3}\right.$ x $2, \mathrm{OCH}_{3}-\mathrm{C}_{3}, \mathrm{OCH}_{3}-$ $\left.\mathrm{C}_{5}{ }^{\prime}\right), 61.3\left(\mathrm{CH}_{3}, \mathrm{OCH}_{3}-\mathrm{C}_{3}\right.$ "), 105.8 (CH x 2, C-2', C-6'), 110.9 (CH, C-2”), 115.2 (CH, C-5”), 121.2 (CH, C-6”), 122.4 (C, C-5), 134.7 (C, C-1'”), 136.7 (C x 2, C-1', C-4'), 146.5 (C, C-4'”), 147.4 (C, C-4), 153.6 (C x 3, C-3', C-5', C-3”); IR (NaCl): v' 3540 (OH), 3440 (NH), 1593 (C=C), 1240 (ArO), $1130(\mathrm{C}-\mathrm{O}) \mathrm{cm}^{-1}$; MS (ESI(+)): m/z $394[\mathrm{M}+\mathrm{Na}]^{+}$. HRMS (ESI): m/z $372.1574[\mathrm{M}+\mathrm{H}]^{+}$, $\mathrm{C}_{19} \mathrm{H}_{22} \mathrm{~N}_{3} \mathrm{O}_{5}$ requires 372.1559 .

\subsubsection{4-(3-Indolemethyl)-5-(3,4,5-trimethoxyphenyl)-1,2,3-triazole (21).}

General procedure 4.1.4. was applied to 1-(3-indolemethyl)-2-(3,4,5-trimethoxybenzyl)-1nitroethene (13) (1.00 g, $2.70 \mathrm{mmol})$ with a reaction time of $12 \mathrm{~h}$. The crude product was purified by chromatography on silica gel $\left(\mathrm{CH}_{2} \mathrm{Cl}_{2} / \mathrm{MeOH} 95 / 5\right)$ and then treated to eliminate remaining DMSO according to general procedure 4 to provide the expected compound as a brown solid (0.92 g, $2.52 \mathrm{mmol}, 93 \%$ ). Mp: 122-123 ${ }^{\circ} \mathrm{C}$ (benzene/acetone); ${ }^{1} \mathrm{H}-\mathrm{NMR}\left(300 \mathrm{MHz}, \mathrm{CDCl}_{3}\right): \delta=3.52$ (s, $6 \mathrm{H}, \mathrm{OCH}_{3}-\mathrm{C}_{3}, \mathrm{OCH}_{3}-\mathrm{C}_{5}$ ), $3.83\left(\mathrm{~s}, 3 \mathrm{H}, \mathrm{OCH}_{3}-\mathrm{C}_{4}\right.$ ), 4.28 (s, 2H, $\left.\mathrm{CH}_{2}\right), 6.67$ (s, 1H, H-2"), 6.82 (s, 2H, H-2', H-6'), 7.12 (t, J=7.4 Hz, 1H, H-6”), 7.18 (t, $J=7.4$ Hz, 1H, H-5”), 7.29 (d, J = $8.0 \mathrm{~Hz}$, 1H, H-7”), 7.52 (d, $J=8.2 \mathrm{~Hz}, 1 \mathrm{H}, \mathrm{H}-4 ”), 8.17$ (s, 1H, NH indole); ${ }^{13} \mathrm{C}-\mathrm{NMR}$ (75 MHz, DMSO): $\delta=22.6\left(\mathrm{CH}_{2}, \mathrm{CH}_{2}-\mathrm{Ar}\right), 55.9\left(\mathrm{CH}_{3}\right.$ x 2, $\left.\mathrm{OCH}_{3}-\mathrm{C}_{3}, \mathrm{OCH}_{3}-\mathrm{C}_{5}{ }^{\prime}\right), 60.5\left(\mathrm{CH}_{3}, \mathrm{OCH}_{3}-\mathrm{C}_{4}\right), 104.8(\mathrm{CH} \times$ 2, C-2', C-6'), 111.9 (C, C-3”), 112.4 (C, C-3”a), 118.8 (CH x 2, C-5”, C-6”), 121.8 (CH, C-2”), 123.6 (CH, C-4”), 127.2 (CH, C-7”), 133.0 (C, C-1'), 136.7 (C, C-5), 142.8 (C, C-7”a), 143.8 (C, C-4), 153.7 (C x 3, C-3', C-4', C-5'); IR (NaCl): v' 3478 (NH-indole), 3009 (NH), 1589 (C=C), 1239 (Ar-O), 1128 (C-O) $\mathrm{cm}^{-1}$; HRMS (ESI): m/z $365.1625[\mathrm{M}+\mathrm{H}]^{+}, \mathrm{C}_{20} \mathrm{H}_{21} \mathrm{~N}_{4} \mathrm{O}_{3}$ requires 365.1614 .

4.1.5. 5-(3-Amino-4-methoxyphenyl)-4-(3,4,5-trimethoxybenzyl)-1,2,3-triazole (22). 
Compound 22 was obtained by reduction of the nitro group in $\mathbf{1 7}(0.43 \mathrm{~g}, 1.07 \mathrm{mmol})$ via catalytic hydrogenation with a reaction time of $1 \mathrm{~h}$, using 10\% w/w of Pd/C as a catalyst and THF as the solvent. The reaction mixture was filtered over a Celite surface to eliminate the $\mathrm{Pd} / \mathrm{C}$ and thoroughly rinsed with acetone. The solvents were then evaporated under vacuum and the crude product was purified by chromatography on silica gel $\left(\mathrm{CH}_{2} \mathrm{Cl}_{2} / \mathrm{MeOH} 96 / 4\right)$ to provide the expected compound as a bright white foamy solid $(0.35 \mathrm{~g}, 0.94 \mathrm{mmol}, 88 \%)$. Mp: $112-113{ }^{\circ} \mathrm{C}$ (benzene/acetonitrile); ${ }^{1} \mathrm{H}-\mathrm{NMR}\left(300 \mathrm{MHz}, \mathrm{CDCl}_{3}\right): \delta=3.74\left(\mathrm{~s}, 6 \mathrm{H}, \mathrm{OCH}_{3}-\mathrm{C}_{3}, \mathrm{OCH}_{3}-\mathrm{C}_{5}\right.$ ), 3.80 (s, $3 \mathrm{H}, \mathrm{OCH}_{3}-\mathrm{C}_{4}{ }^{\prime}$ ), 3.86 (s, 3H, $\mathrm{OCH}_{3}-\mathrm{C}_{4}$ ), 4.15 (s, 2H, $\mathrm{CH}_{2}-\mathrm{Ar}$ ), 6.40 (s, 2H, H-2', H-6'), 6.79 (d, J $=8.0 \mathrm{~Hz}, 1 \mathrm{H}, \mathrm{H}-5 "), 6.92$ (dd, $\left.J_{1}=8.0 \mathrm{~Hz}, J_{2}=2.0 \mathrm{~Hz}, 1 \mathrm{H}, \mathrm{H}-6 "\right), 6.98$ (d, $\left.J=2.0 \mathrm{~Hz}, 1 \mathrm{H}, \mathrm{H}-2 "\right)$;

${ }^{13} \mathrm{C}-\mathrm{NMR}\left(75 \mathrm{MHz}, \mathrm{CDCl}_{3}\right): \delta=31.5\left(\mathrm{CH}_{2}, \mathrm{CH}_{2}-\mathrm{Ar}\right), 55.6\left(\mathrm{CH}_{3}, \mathrm{OCH}_{3}-\mathrm{C}_{4}{ }^{\prime \prime}\right), 56.2\left(\mathrm{CH}_{3}\right.$ х 2 , $\left.\mathrm{OCH}_{3}-\mathrm{C}_{3}, \mathrm{OCH}_{3}-\mathrm{C}_{5}{ }^{\prime}\right), 61.0\left(\mathrm{CH}_{3}, \mathrm{OCH}_{3}-\mathrm{C}_{4}{ }^{\prime}\right), 105.5$ (CH x 2, C-2', C-6'), 110.5 (CH, C-5”), 114.4 (CH, C-2”), 118.1 (CH, C-6”), 122.8 (C, C-1”), 134.4 (C, C-1'), 136.5 (C x 2, C-4, C-5), 143.1 (C, C-3”), 147.7 (C, C-4”), 153.2 (C x 3, C-3', C-4', C-5'); IR (NaCl): v' 3007 (NH), 1592 (C=C), 1240 (Ar-O), 1129 (C-O) $\mathrm{cm}^{-1}$; HRMS (ESI): m/z $371.1729[\mathrm{M}+\mathrm{H}]^{+}, \mathrm{C}_{19} \mathrm{H}_{22} \mathrm{~N}_{3} \mathrm{O}_{5}$ requires 371.1719 .

\subsection{Biological evaluation procedures}

\subsubsection{Endothelial cell morphology.}

To assess the effects of the compounds on the morphology of endothelial cells, we used the EAhy 926 endothelial cell line which is derived from the fusion of human umbilical vein endothelial cells (HUVEC) with the permanent human cell line A549 [55]. The EAhy 926 cell line is considered as one of the best immortalized HUVEC cell lines because these cells express most of the biochemical markers of parental HUVEC EAhy 926 cells [56]. EAhy 926 cells were grown in DMEM containing $2 \mathrm{mM}$ L-glutamine, $10 \%$ fetal bovine serum, $100 \mathrm{U} / \mathrm{mL}$ penicillin and $100 \mu \mathrm{g} / \mathrm{mL}$ streptomycin $\left(37^{\circ} \mathrm{C}, 5 \% \mathrm{CO}_{2}\right)$. Exponentially growing EAhy 926 cells were plated onto 96 well plates at 5000 cells/100 $\mu \mathrm{L} /$ well. Twenty-four hours after plating, the medium was aspirated, and $100 \mu \mathrm{L}$ of medium containing the test compound was added to the well containing the cells (in triplicate) and incubated for $2 \mathrm{~h}\left(37^{\circ} \mathrm{C}, 5 \% \mathrm{CO}_{2}\right)$. The highest concentration used was $100 \mu \mathrm{M}$ followed by serial two-fold dilutions down to low nanomolar concentrations, if needed for the most morphologically active compounds. After the $2 \mathrm{~h}$-incubation period, digital photographs were taken of representative centre areas of each well at a magnification of $100 \mathrm{X}$ and $200 \mathrm{X}$. The results are presented as the minimum concentration that could elicit the rounding up of more than $15 \%$ of cells in a field in order to exclude normal mitotic cells which is less that $15 \%$ in control $1 \%$ DMSO 
treated cells. Triplicate concentrations on the same plate were routinely carried out. CA4 was included in the experiments as internal standard.

\subsubsection{Inhibition of tubulin polymerization.}

Tubulin microtubule assembly in microtubules was carried out using the fluorescent dye DAPI (4',6-diamidino-2-phenylindole) [57] in a 96-well plate format as described [58, 59]. The standard assay was performed as follows: wells were charged with tubulin (Cytoskeleton, 97\% pure, final concentration $1 \mathrm{mg} / \mathrm{ml}$ ) in PME buffer (100 mM PIPES (1,4-piperazinebis(ethanesulfonic acid); 1 $\mathrm{mM} \mathrm{MgSO}{ }_{4} ; 2 \mathrm{mM}$ EGTA) with $10 \mu \mathrm{M}$ DAPI and varying concentrations of the test compounds using colchicine at $30 \mu \mathrm{M}$ as an internal positive control. The final concentrations used for the test compounds were started at $30 \mu \mathrm{M}$ and diluted in 3-fold decrements thereafter until no inhibition was observed. Triplicate wells were run for each concentration. After a preincubation of $45 \mathrm{~min}$ at room temperature, $5 \mu 1$ of $1 \mathrm{mM}$ GTP was added to each well to initiate tubulin polymerization, and the plate was then transferred to a thermostated Victor plate reader at $37{ }^{\circ} \mathrm{C}$ for an additional $2 \mathrm{~h}$. Fluorescence was then read at the excitation wavelength of $360 \mathrm{~nm}$ and emission of $450 \mathrm{~nm}$. The percent inhibition was determined as follows: $1-(\Delta \mathrm{F}$ (sample/ $\Delta \mathrm{F}$ (control) $\mathrm{X} 100$, where $\Delta \mathrm{F}$ control $=\mathrm{F}($ no inhibition $)-\mathrm{F}($ complete inhibition $)$, and $\Delta \mathrm{F}$ sample $=\mathrm{F}$ (sample $)-\mathrm{F}$ (complete inhibition with colchicine). The $\mathrm{IC}_{50}$ for compound-induced inhibition of tubulin polymerization is the concentration at which the extent of inhibition of polymerization is $50 \%$ of the maximum value as determined from the semi-logarithmic plot of percent inhibition as a function of the logarithm of drug concentration fitted to a sigmoidal model with variable slope using the nonlinear regression program SigmaPlot (Jandel Scientific). In these conditions the $\mathrm{IC}_{50}$ value for colchicine inhibition of tubulin polymerization was $0.36 \mu \mathrm{M}$.

\subsubsection{Cytotoxicity assay.}

Murine B16 melanoma cells were grown in DMEM medium containing $2 \mathrm{mM}$ L-glutamine, 10\% foetal bovine serum, $100 \mathrm{U} / \mathrm{mL}$ penicillin and $100 \mu \mathrm{g} / \mathrm{mL}$ streptomycin $\left(37^{\circ} \mathrm{C}, 5 \% \mathrm{CO}_{2}\right)$. All compounds were initially dissolved in DMSO at a stock concentration of $2.5 \mathrm{mg} / \mathrm{mL}$ and were further diluted in cell culture medium. Exponentially growing cells were plated onto 96-well plates at 5000 cells per well in $100 \mu \mathrm{l}$ of culture medium. Twenty-four h after plating, $100 \mu \mathrm{l}$ of medium containing the compound at final concentrations ranging from 0.01 to $100 \mu \mathrm{M}$ were added to the wells (in triplicate) containing the cells, and incubated for $48 \mathrm{~h}$ at $37{ }^{\circ} \mathrm{C}$ and $5 \% \mathrm{CO}_{2}$. After the $48 \mathrm{~h}$ exposure period to the test compounds, cell viability was assayed using the MTT test [60] and absorbance was read at $562 \mathrm{~nm}$ in a microplate reader (BioKinetics Reader, EL340). Appropriate 
controls with DMEM only and MTT were run to subtract background absorbance. The concentration of compound that inhibited cell viability by $50 \%$ (inhibitory concentration for $50 \%$ of cells, or $\mathrm{IC}_{50}$ ) was determined using the GraphPad Prism software.

\subsubsection{Docking protocol}

Our previous docking work on analogues of Combretastatin A4 [47] implied GOLD (Genetic Optimisation for Ligand Docking), so we performed our study with this software in its new version [50].

\section{Ligands preparation}

Three compounds, CA4, 11 and 19 were initially built within MarvinSketch 5.8.0 from Chemaxon [61] next submitted to Corina [62], a 3D structure generator. Obtained 3D conformations were next submitted to Ligprep from the Schrödinger software suite [63] in order to generate tautomers forms. Regarding a $\mathrm{pH}=7.0+/-2.0$ three forms were found for $\mathbf{1 9}$ where $\mathrm{H}$ atom can be bound to the three $\mathrm{N}$ atoms of the triazole ring. Due to the high level of flexibility of the previously structures conformational analyses, according to the OPLS2005 force field [64], were computed and the lowest energy conformations were kept as input for the docking stage.

\section{Protein preparation}

3D structure of tubulin was retrieved from the Protein Data Bank (http://www.rcsb.org, PDB ID: 1SA0) [46]. Subunits C, D and E were removed. Only subunits A, B, corresponding to the colchicine binding site, and small molecules DAMA-colchicine (CN2), GTP and $\mathrm{Mg}^{2+}$ ion in this site were conserved.

\section{Molecular docking}

Docking runs were performed with an exploration of the conformational space of ligands more important than with default parameters in that sense that 100 conformations were kept for each ligand and early termination process (run will stop after 3 conformations found within an RMSD of $1.5 \AA$ A) was disabled. Goldscore was chosen again as our fitness scoring function.

\subsubsection{Antitumor evaluation in mice.}

Female BALB/cJRj mice (average weight, $18 \mathrm{~g}$ ) obtained from Janvier (Le Genest St Isle, France) were supplied food and water ad libitum. Colon 26 tumor fragments (30 to $60 \mathrm{mg}$ ) were implanted bilaterally in the axillary region by subcutaneous injection on day 0 with a 12 gauge trocar [65]. Bilateral implants were used to insure a more uniform tumor burden per mouse. The methods of protocol design, chemotherapy techniques, and data analysis have been presented in detail 
elsewhere $[66,67]$. Briefly, the animals were pooled before distribution to the various treatment and control groups ( 5 mice per group) and preliminary experiments in non tumored animals allowed to determine the maximum tolerated dose which was $150 \mathrm{mg} / \mathrm{kg}$ for $\mathbf{1 1}$ and $100 \mathrm{mg} / \mathrm{kg}$ for $\mathbf{1 9}$, when administered intraperitoneally for two weeks on days 3-7 and 10-14 after tumor implantation (day 0). Compounds were freshly prepared daily in saline containing 5\% DMSO and 5\% polysorbate 80 and injected intraperitoneally in a volume of $0.2 \mathrm{ml}$. Mice were weighed daily and checked for clinical signs of toxicity. Tumors were measured daily with a caliper and tumor volumes $\left(\mathrm{mm}^{3}\right)$ were estimated from two dimensional tumor measurements $(\mathrm{mm})$ : Tumor volume $\left(\mathrm{mm}^{3}\right)=($ length $\times$ width $\left.{ }^{2} \times 0.5\right)$. The end points used to determine the antitumor activity were the percent $\mathrm{T} / \mathrm{C}$ value and the tumor growth delay (T-C value). The $\% \mathrm{~T} / \mathrm{C}$ was calculated when the tumor volume reached $1500 \mathrm{~mm}^{3}$ for the controls $(\mathrm{C})$. The T/C value in percent is calculated as follows: T/C $(\%)=$ (median tumor weight of the Treated / median tumor weight of the Control) $\times 100$. According to the National Cancer Institute (NCI) standards, a T/C of $42 \%$ is the minimum level for activity. The tumor growth delay (T-C value) was calculated based on the median time (in days) required for the treatment group $(\mathrm{T})$ and the control group $(\mathrm{C})$ tumors, to reach the size of $1500 \mathrm{~mm}^{3}$. 


\section{Acknowledgements}

This work was financially supported by the Centre National de la Recherche Scientifique (CNRS), the Institut National de la Santé et de la Recherche Médicale (Inserm), the Institut Curie and by a grant from the Institut National du Cancer (INCa, Boulogne Billancourt, France). We are also grateful to the University of Barcelone for a studentship (to Núria Mur Blanch). 


\section{References}

[1] D. W. Siemann, D. J. Chaplin, M. R. Horsman, Cancer 100 (2004) 2491-2499. [1]

[2] P. E. Thorpe, Clin. Cancer Res. 10 (2004) 415-427.

[3] D. Neri, R. Bicknell, Nature Rev. Cancer 5 (2005) 436-446.

[4] D. J. Chaplin, M. R. Horsman, D. W. Siemann, Curr. Opin. Investig. Drugs 7 (2006) 522-528.

[5] C. Kanthou, G. M. Tozer, Expert Opin. Ther. Targets 11 (2007) 1443-1457.

[6] C. A. Honstvet, P. F. Jones, Comput. Math. Methods Med. 8 (2007) 1-9.

[7] C. Kanthou, G. M. Tozer, Int. J. Exp. Pathol. 90 (2009) 284-294.

[8] V. L. Heath, R. Bicknell, Nat. Rev. Clin. Oncol. 6 (2009) 395-404.

[9] M. Ham Fens, G. Storm, R. M. Schiffelers, Expert Opin. Ther. Targets 19 (2010) 1321-1338.

[10] L. G. M. Daenen, J. M. L. Roodhart, Y. Shaked, E. E. Voest, Curr. Clin. Pharmacol. 5 (2010) 178

[11] G. M. Tozer, C. Kanthou, C. S. Parkins, S. A. Hill, Int. J. Exp. Pathol. 83 (2002) 2138.

[12] G. M. Tozer, C. Kanthou, B. C. Baguley, Nature Rev. Cancer 5 (2005) 423-435.

[13] D. W. Siemann, M. C. Bibby, G. G. Dark, A. P. Dicker, F. A. Eskens, M. R. Horsman, D. Marmé, P. M. Lorusso, Clin. Cancer Res. 11 (2005) 416-420.

[14] R. S. Kerbel, N. Engl. J. Med. 358 (2008) 2039-2049.

[15] D. W. Siemann, Cancer Treat Rev. 37 (2011) 63-74.

[16] R. P. Mason, D. Zhao, L. Liu, M. L. Trawick, K. G. Pinney, Integr. Biol. 3 (2011) 375-387.

[17] G. R. Pettit, G. M. Cragg, D. L. Herald, J. M. Schmidt, P. Lohavani-jaya, Can. J. Chem. 60 (1982) 1374-1376.

[18] G. R. Pettit, G. M. Cragg, S. B. Singh, J. Nat. Prod. 50 (1987) 386.

[19] G. R. Pettit, S. B. Singh, E. Hamel, C. M. Lin, D. S. Alberts, D. Garcia-Kendall, Experientia 45 (1989) 209-211.

[20] C. M. Lin, S. B. Singh, P. S. Chu, R. O. Dempey, J. M. Schmidt, G. R. Pettit, E. Hamel, Mol. Pharmacol. 34 (1988) 200-208.

[21] I. G. Kirwan, P. M. Loadman, D. J. Swaine, D. A. Anthoney, G. R. Pettit, J. W. Lippert III, S. D. Shnyder, P. A. Cooper, M. C. Bibby, Clin. Cancer Res. 10 (2004) 1446-1453. 
[22] S. Aprile, E. Del Grosso, G. C. Tron, G. Grosa, Drug Metab. Dispos. 35 (2007) 2252-2261.

[23] N. -H. Nam, Current Medicinal Chemistry 10 (2003) 1697-1722.

[24] A. Cirla, J. Mann, J. Nat. Prod. Rep. 20 (2003) 558-564.

[25] K. G. Pinney, C. Jelinek, K. Edvardsen, D. J. Chaplin, G. R. Pettit. In: G. M. Cragg, -D. G. I. Kingston, D. J. Newman (Eds), Anticancer Agents from Natural Products,. Taylor \& Francis Group, Boca Raton, 2005, pp. 23-46.

[26] H. P. Hsieh, J. P. Liou, N. Mahindroo, Curr. Pharm. Design, 11 (2005) 1655-1677.

[27] T. Brown, H. Holt Jr., M. Lee, in: Top Heterocycl. Chem. 2, Springer-Verlag, Berlin Heidelberg, 2006, pp 1-51.

[28] G. C. Tron, T. Pirali, G. Sorba, F. Pagliai, S. Busacca, A. Genazzani, J. Med. Chem. 49 (2006) 3033-3044.

[29] A. Brancale, R. Silvestri, Med. Res. Rev. 27 (2007) 209-238.

[30] Chaudhary, Anurag; S. N. Pandeya, P. Kumar, P. P. Sharma, S. Gupta, N. Soni, K. K. Verma, G. Bhardwaj, Mini Rev. Med. Chem. 7 (2007) 1186-1205.

[31] Y. Shan, J. Zhang, Z. Liu, M. Wang, Y. Dong, Curr. Med. Chem. 18 (2011) 523-538.

[32] M. Marrelli, F. Conforti, G. A. Statti, X. Cachet, S. Michel, F. Tillequin, F. Menichini, Curr. Med. Chem. 18 (2011) 3035-3081.

[33] K. Ohsumi, T. Hatanaka, K. Fujita, R. Nakagawa, Y. Fukuda, Y. Nihei, Y. Suga, Y. Morinaga, Y. Akiyama, T. Tsuji, Bioorg. Med. Chem. Lett. 8 (1998) 3153-3158.

[34] Q. Zhang, Y. Peng, X. I. Wang, S. M. Keenan, S. Arora, W. J. Welsh, J. Med. Chem. 50 (2007) 749-754.

[35] F. Pagliai, T. Pirali, E. Del Grosso, R. Di Brisco, G. C. Tron, G. Sorba, A. Genazzani, J. Med. Chem. 49 (2006) 467-470.

[36] K. Odlo, J. Hentzen, J. Fournier dit Chabert, S. Ducki, O. A. B. S. M. Gani, I. Sylte, M. Skrede, V. A. Flørenes, T. V. Hansen, Bioorg. Med. Chem. 16 (2008) 4829-4838.

[37] K. Odlo, J. Fournier dit Chabert, S. Ducki, O. A. B. S. M. Gani, I. Sylte, T. V. Hansen, Bioorg. Med. Chem. 18 (2010) 6874-6885.

[38] Ø. W. Akselsen, K. Odlo, J.-J. Cheng, G. Maccari, M. Botta, T. V. Hansen, Bioorg. Med. Chem. 20 (2012) 234-242.

[39] L. Cafici, T. Pirali, F. Condorelli, E. Del Grosso, A. Massarotti, G. Sorba, P. L. Canonico, G. C. Tron, A. J. Genazzani, J. Comb. Chem. 10 (2008) 732-740.

[40] Z. Demko, C. Borella, S. Chen, L. Sun, U.S. Patent 2007238699 A1, oct. 11, 2007. 
[41] H. N. Pati, M. Wicks, H. L. Holt Jr., R. LeBlanc, P. Weisbruch, L. Forrest, M. Lee, Heterocycl. Commun. 11 (2005) 117-120.

[42] O. Mezenzani, A. Massarotti, M. Giustiniano, T. Pirali, V. Bevilacqua A. Caldarelli, P. Canonico, G. Sorba, E. Novellino, A. A. Genazzani, G. C. Tron, Bioorg. Med. Chem. Lett. 21 (2011) 764-768.

[43] D. Dauzonne, R. Royer, Chem. Pharm. Bull. 34 (1986) 1628-1633.

[44] B. Quiclet-Sire, S. Z. Zard Synthesis (2005) 3316-3326.

[45] S. M. Galbraith, D. J. Chaplin, F. Lee, M. R. Stratford, R. J. Locke, B.Vojnovic, G. M. Tozer, Anticancer Res. 21 (2001) 93-102

[46] R. B. G. Ravelli, B. Gigant, P. A. Curmi, I. Jourdain, S. Lachkar, A. Sobel, M. Knossow, Nature 428 (2004) 198-202.[47] M. Arthuis, R. Pontikis, G. G. Chabot, J. Seguin, L. Quentin, S. Bourg, L. Morin-Allory, J.-C. Florent, Chem. Med. Chem. 6 (2011) 1693-1705.[48] M. Botta, S. Forli, M. Magnani, F. Manetti, Top. Curr. Chem. 286 (2009) 279-328.

[49] A. Massaroti, A. Coluccia, R. Silvestri, G. Sorba, A. Brancale, Chem. Med. Chem., 7 (2012) 33-42.

[50] G. Jones, P. Willet, R. C. Glen, J. Mol. Biol., 245 (1995) 43-53

[51] R. Álvarez, C.Álvarez, F. Mollinedo, B. G. Sierra, M. Medarde, R. Peláez, Bioorg. Med. Chem., 17 (2009), 6422-6431.

[52] T.H. Corbett, M.C. Bissery, A. Wozniak, J. Plowman, L. Polin, E. Tapazoglou, J. Dieckman, F. Valeriote, Invest. New Drugs, 4 (1986) 207-220.

[53] A. K. Sinhababu, R. T. Bordchardt, Tetrahedron Letters 24 (1983) 227-230.

[54] D. Dauzonne, P. Demerseman, Synthesis (1990) 66-70.

[55] C. J. Edgell, C. C.; McDonald, J. B. Graham, Proc. Natl. Acad. Sci. U S A 80 (1983) 3734-3737.

[56] D. Bouis, G. A. Hospers, C. Meijer, G. Molema, N. H. Mulder, Angiogenesis 4 (2001) 91-102.

[57] D. Bonne, C. Heusele, C. Simon, D. Pantaloni, J. Biol. Chem. 260 (1985) 2819-2825.

[58] D. M. Barron, S. K. Chatterjee, R. Ravindra, R. Roof, E. Baloglu, D. G. Kingston, S. Bane, Anal. Biochem. 315 (2003) 49-56.

[59] S. L. Bane, R. Ravindra, A. A. Zaydman, in: J. Zhou (Ed.), Microtubule Protocols, Humana Press, Totowa, New Jersey, 2007, pp 281-288.

[60] D. A. Scudiero, R. H. Shoemaker, K. D. Paull, A. Monks, S. Tierney, T. H. Nofziger, M. J. Currens, D. Seniff, M. R. Boyd, Cancer Res. 48 (1988) 4827-4833.

[61] Marvin 5.8.0, 2012, http://www.chemaxon.com 
[62] a) J. Sadowski, J. Gasteiger, Chem. Rev., 93 (1993) 2567-2581.

b)CORINA - Fast Generation of High-Quality 3D Molecular Models:

http://www.molecular-networks.com/products/corina

[63] Schrödinger Suite, version 2011 update 1, Schrödinger, Inc., New York, 2012

[64] G. A. Kaminski, R. A. Friesner, J. Tirado-Rives, W. Jorgensen, J. Phys. Chem. B, 105 (2001) 6474-6487

[65] T.H. Corbett, D.P. Griswold, Jr., B.J. Roberts, J.C. Peckham, F.M. Schabel, Jr., Cancer, 40 (1977) 2660-2680.

[66] T.H. Corbett, W.R. Leopold, D.J. Dykes, B.J. Roberts, D.P. Griswold, Jr., F.M. Schabel, Jr., Cancer Res., 42 (1982) 1707-1715.

[67] M.C. Bissery, P. Vrignaud, F. Lavelle, G.G. Chabot, Ann. N. Y. Acad. Sci, 803 (1996) 173-180. 


\section{Legends for Figures}

Figure 1. Morphological effects on endothelial cells. Typical rounding up of endothelial cells (EAhy 926) exposed to CA4 $1(0.006 \mu \mathrm{M})$ and compound $19(1 \mu \mathrm{M})$ for a 2 hour exposure time. The solvent DMSO 1\% was used as the control. Original magnification, $200 \mathrm{X}$.

Figure 2. Correlation between rounding up activity on endothelial cells and inhibition of tubulin polymerization (ITP). Compounds with good morphological activity (rounding up concentration $<10 \mu \mathrm{M}$ ) are plotted against the concentration needed to inhibit tubulin polymerization by $50 \%\left(\mathrm{IC}_{50}\right)$. Equation of the straight line: $\mathrm{Y}=4.396 \mathrm{X}, \mathrm{r}^{2}=0.834$.

Figure 3. Putative binding of our best cis-constrained analogues of CA4. For clarity non polar hydrogen atoms are not represented.

Top: CA4 docking pose (green stick model) is superimposed to crystallographic CN-2 (damacolchicine, gray stick model), reproducing the binding mode highlighted in the colchicine domain of the crystallographic complex (PDB ID: 1SA0). $\alpha$ and $\beta$-tubulin are ribbons displayed according to their secondary structure. Residues of the three zones of interaction [49] are represented too (zone 1: cyan, zone 2: orange, zone 3: green). Val181 $\alpha$ from zone 1 and Cys241 $\beta$ from zone 2 are highlighted (tube, element colored) as they are involved in $\mathrm{H}$ bonds represented in yellow dashed lines.

Down: superimposition of CA4 (green tube), 11 (pink tube) and the best docking scored tautomer of 19 (grey tube). Concerning the compound 19, similar conformations, not shown, were obtained regardless the tautomer forms. The right part represents a $90^{\circ}$ rotation about the vertical axis of the left view and highlights the conservation of the cisoid arrangement of the two aromatic rings.

Figure 4. Antitumor effects of compounds 11 and 19. Mice bearing subcutaneously implanted colon 26 carcinoma tumors were treated intraperitoneally with solvent (Control) or with compound 11 or 19 for 2 weeks on days 3 to 7, and days 10 to 14, as describe in the Experimental protocols section. 

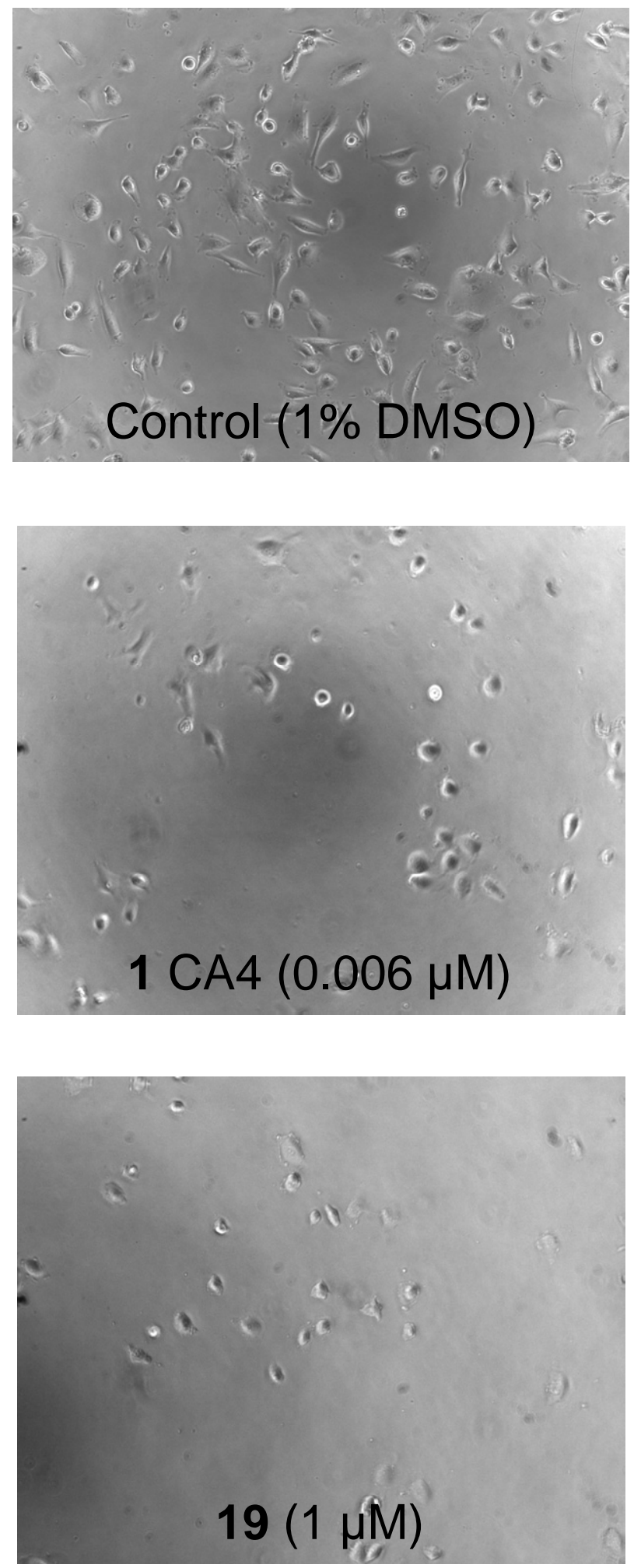

Figure 1 


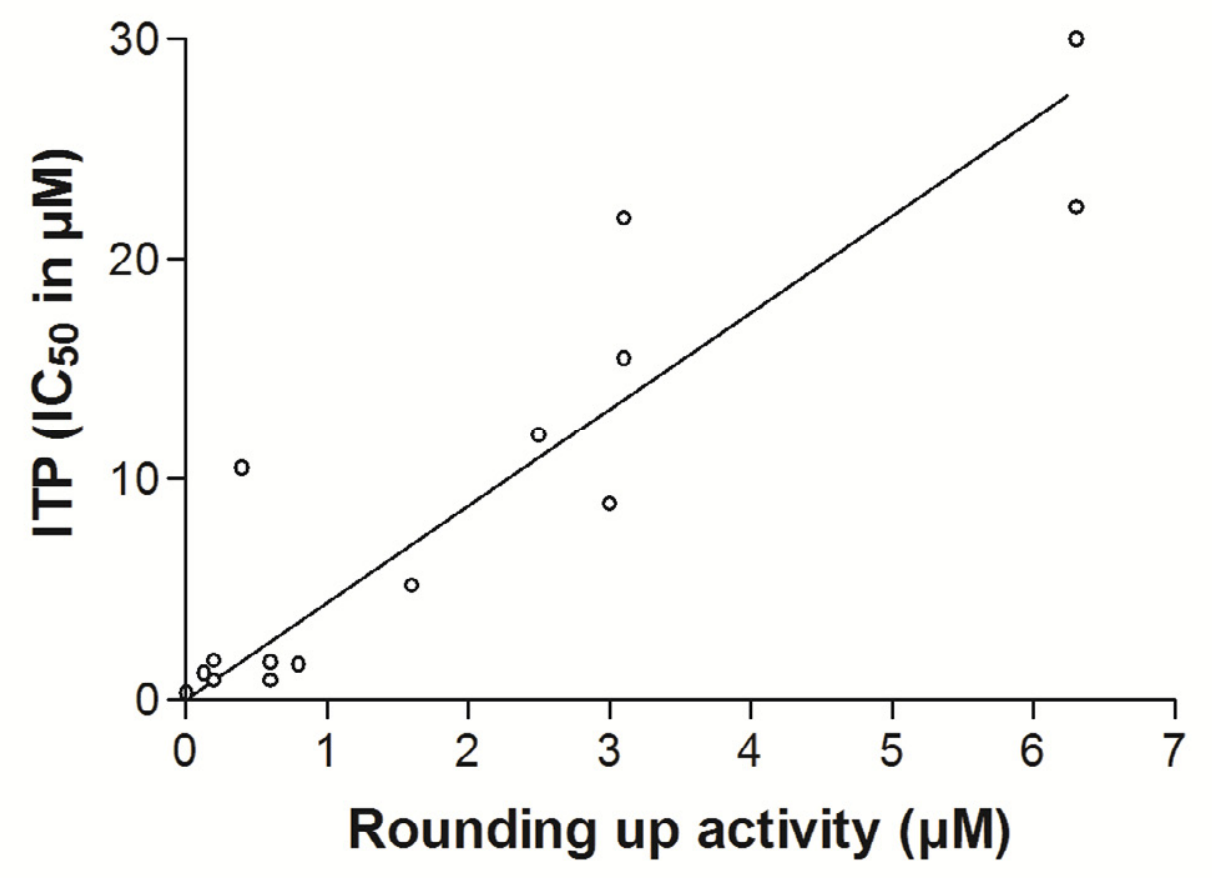

Figure 2 

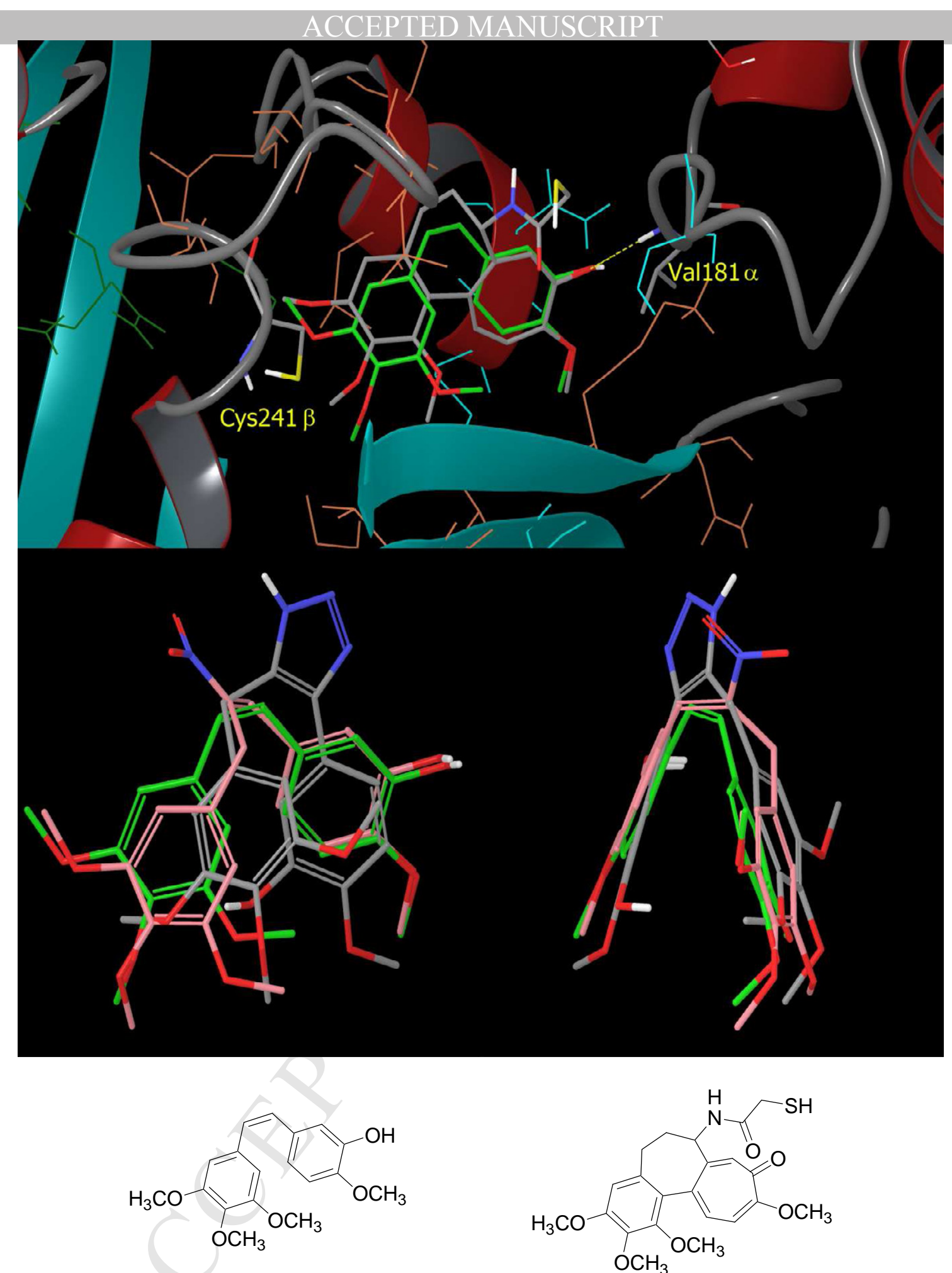

\section{CA4 1}

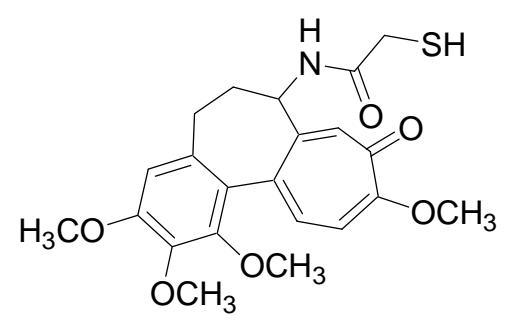

DAMA-colchicine

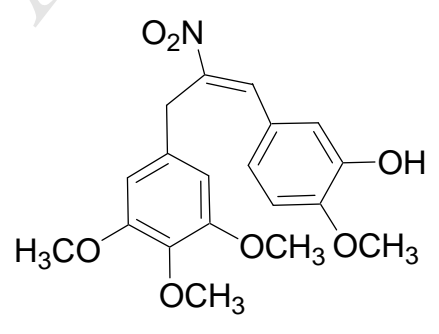

11

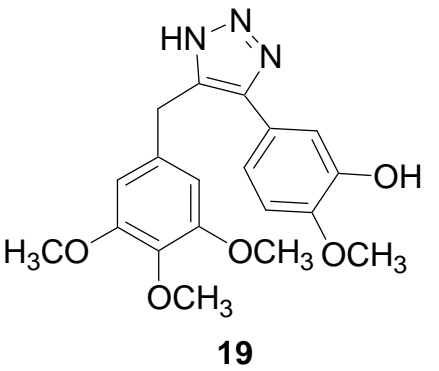

19

Figure 3 


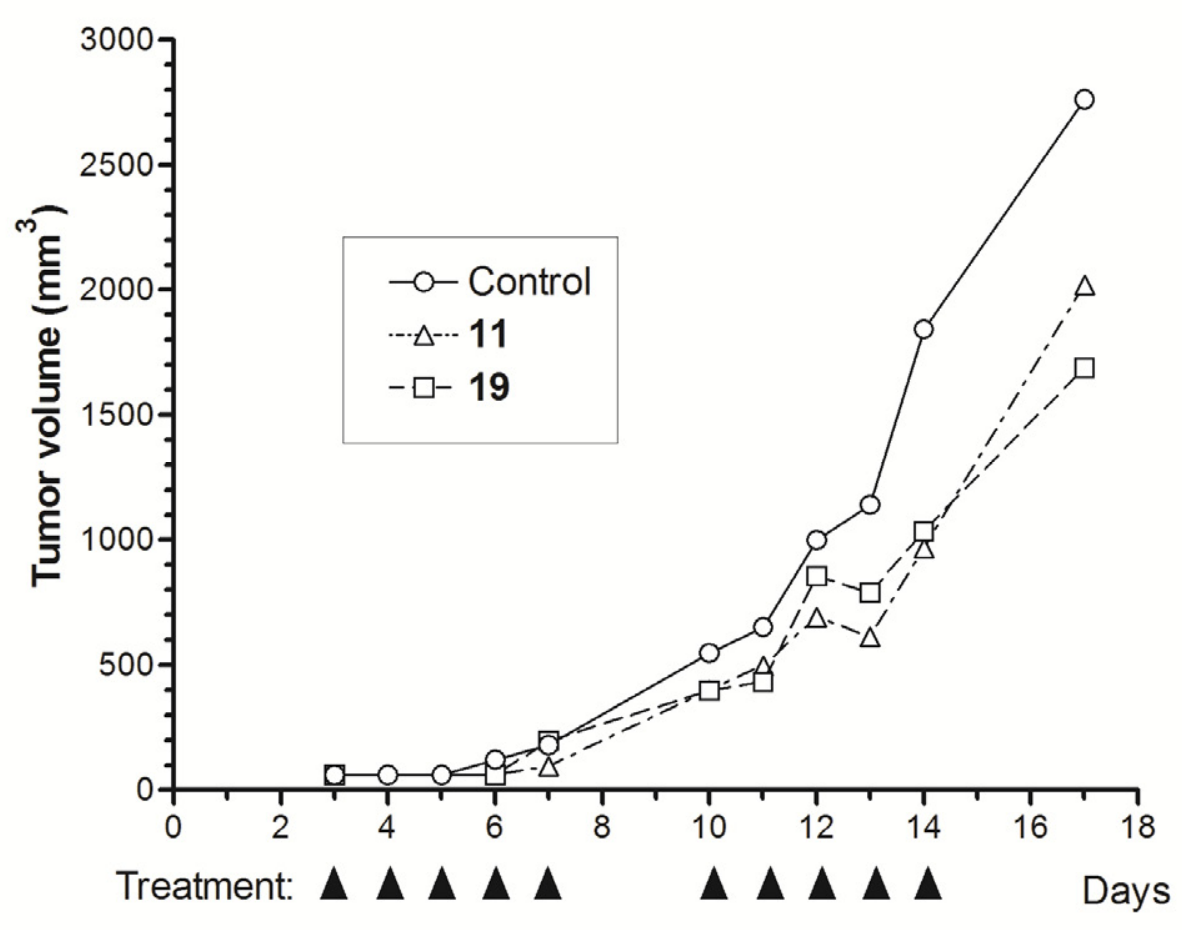

Figure 4 